\title{
1550 ㄷに至る高温度の計測の信頼性向上
}

\section{—＼cjkstart熱電対のための温度の標準体系構築}

\begin{abstract}
新井 優*、小倉 秀樹、井土 正也
1990年代後半から、熱電対による1550 ํまでの温度計測のための国家計量標準を整備し、それに基づく標準体系を構築して、高温域 の温度計測の信頼性を向上させた。温度の国家計量標準が何段階かの校正の連鎖を経て、実際の計測に使われる熱電対に移転され る仕組み (トレーサビリテイ体系) を、標準器の利用の容易さ、校正事業者と産総研との役割分担など、多くの要素を考慮に入れて設計 した。新しく開発した標準技術と、現在までに民間企業が培ってきた技術とを適切に融合させて、新しい技術の普及を見定めながら、 全体として我が国にとって最も望ましいトレーサビリティ体系を構築した。
\end{abstract}

キーワード:熱電対、計量標準、校正、温度定点、共晶点

\section{Improving the reliability of temperature measurements up to $1550{ }^{\circ} \mathrm{C}$}

- Establishing the temperature standards and calibration system for thermocouples -

Masaru Arai*, Hideki Ogura and Masaya Izuchi

\begin{abstract}
Since late 1990's, the reliability of temperature measurements at high temperatures was remarkably upgraded by establishing the national metrology standards for calibration of thermocouples up to $1550{ }^{\circ} \mathrm{C}$, and by implementing the traceability system. The traceability system, structured as a hierarchical link of calibrations between the national metrology standards and practical measurements, was designed in consideration of various elements such as availability of the measurement standards and sharing the responsibility with accredited calibration laboratories. The optimized scheme for industries in Japan was established by promoting a balanced combination of conventional techniques held by accredited calibration laboratories and progressive technology, taking into account the spread of the progressive technology.
\end{abstract}

Keywords: Thermocouple, measurement standard, calibration, temperature fixed point, eutectic point

\section{1 はじめに}

本稿は、産業界から温度計測の信頼性の向上が求めら れる中、 $1000{ }^{\circ} \mathrm{C} ら 1550{ }^{\circ} \mathrm{C}$ な゙温度範囲における温 度の国家計量標準を整備し、それに基づいて提供される 温度の標準が校正事業者を介してユーザーに至るまでの体 系を我が国に構築したことを、構成学的に論述したもので ある。計量標準は社会で広く利用されて初めて意味をもつ。 トレーサビリテイの源となる国家計量標準を設定し、それ を計測の現場にまで連鎖させる体系は、現在までに社会 で培われた技術と、新たな目標を達成するために必要な新 規技術を両立させて設計することが望ましい。ここでは、 新しく開発した仲介標準器とその導入の技術的な背景を中 心に、温度計測の信頼性確保のために必要な要素と、そ れらを統合して構築した我が国の高温度の標準体系につい て述べる。

\section{2 高温の計測に対する社会的要請}

$1000{ }^{\circ} \mathrm{C}$ 超え $1550{ }^{\circ} \mathrm{C}$ 付近に至る温度範囲は、鉄鋼業 を始めとする素材産業、熱処理を行う部品製造業、半導体 プロセス産業など多くの場面での温度管理に重要である。 この温度範囲で使われる温度計としては現在熱電対用語 1 が 最も多いことから、熱電対を校正するための温度標準の卜 レーサビリティ体系を作ることが必要であった。

我が国の産業界においては、比較的早い時期 (1960 年 代）から温度計測の信頼性を確保するために関連の学術 団体や工業会などで数多くの調査研究や共同実験が行わ れ、温度計の校正方法や試験方法の規格化が進められて きた。その一つの成果は貴金属熱電対をパラジウムの融解 点 $\left(1553.5{ }^{\circ} \mathrm{C}\right)$ で校正する方法であった。この背景には、 鉄鋼業において溶鋼温度の測定が $1500{ }^{\circ} \mathrm{C}$ 付近で行われ るが、そのときに約 $2{ }^{\circ} \mathrm{C}$ 測定精度が求められたことがあ

産業技術総合研究所 計測標準研究部門 † 305-8563つくば市梅園 1-1-1 中央第 3

National Metrology Institute of Japan, AIST Tsukuba Central 3, 1-1-1 Umezono, Tsukuba 305-8563, Japan * E-mail: masaru-arai@ aist.go.jp

Original manuscript received September 1, 2009, Revisions received January 25, 2010, Accepted February 5, 2010 
る。もう一つの成果は、同じく貴金属熱電対を $1100{ }^{\circ} \mathrm{C}$ 以 下で温度定点用玨 2 を使って校正する方法の共同研究であっ た。この背景には、1980 年代に半導体プロセス産業で要 求が高まりつつあった、 $1100{ }^{\circ} \mathrm{C}$ 付近までの温度範囲で国 際電気標準会議 (IEC) の規格で導入された最も高い精度 のクラス 1 熱電対 ${ }^{[1]}$ に対する技術的要求を確実にクリアし ようという産業界の要請があった。

産業界に打いてこのような努力が払われた一方、当時そ の信頼性のよりどころとなる温度の国家計量標準は十分に 整備されていなかった。このため、産業界で開発された校 正方法と、それによって校正された温度計の信頼性を検証 する手段がなかった。この問題を解決するために取り組ん だのが、ここで述べる温度の国家計量標準の提供と標準 体系の構築である。これは、温度の国家計量標準を整備 し、それをユーザーの温度計にまで伝えていく仕組みを構 築し、さらには温度計の製造事業者や校正事業者が表明 する規格適合や校正值を認証する仕組みを構築することに よって、世の中で広く使われている温度計の信頼性を確保 していこうという活動である。

\section{3 シナリオの設定と要素技術の選択}

\section{1 熱電対のトレーサビリティ}

$1000{ }^{\circ} \mathrm{C}$ から $1550{ }^{\circ} \mathrm{C}$ の間の温度範囲に抢ける温度の国 家計量標準と、それを用いた熱電対のトレーサビリティ体 系の基本的な枠組みを図 1 に示す。

産総研は国家計量標準として温度定点群を保有する。 純粋な銅の凝固点 $\left(1084.62{ }^{\circ} \mathrm{C}\right)$ と純粋な銀の凝固点 $\left(961.78{ }^{\circ} \mathrm{C}\right)$ は、従来から日本を始各国の標準研究機 関で多用されている温度定点である。凝固点の温度值は国 際的な協約のもとで合意して決めたものである。純粋なパ ラジウムの融解点 $\left(1553.5{ }^{\circ} \mathrm{C}\right)$ も高温の温度定点として各 国でしばしば用いられている。

一方金属と炭素の共晶点は、最近日本から提案された新

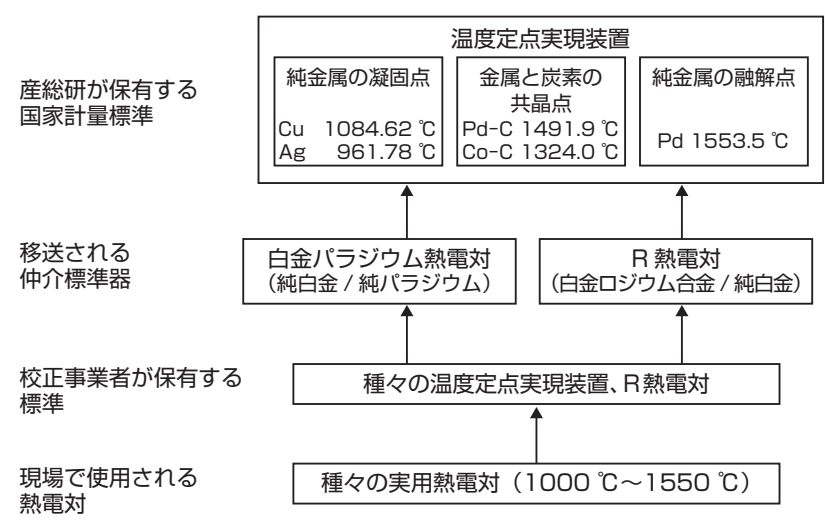

図 1 熱電対のための高温トレーサビリティの基本的枠組み
しい温度定点である。銅の凝固点とパラジウムの融解点の 間にある約 $500{ }^{\circ} \mathrm{C}$ の広い温度範囲に新たな温度定点が利 用可能になることは、温度標準を供給する観点からは大き な意義がある。そこで産総研では可能な限り早期にこれら の金属一炭素共晶点を国家計量標準として利用可能なもの とするべく研究を進めてきた。

産総研が保有する国家計量標準を熱電対の校正を事業 とする校正事業者に伝えるためには、産総研と校正事業者 との間を行き来して温度の標準值を伝える何らかの「仲介 標準器」が必要である。仲介標準器は精密な標準值を伝 えるだけの高い性能を持っていなければならないし、移送 に耐えて正確に標準值を保持し続けるだけの堅牢性がなけ ればならない。また移送に当たっては軽いことや、入手に 当たっては值段が過度に高くないことも現実には重要な項 目である。これらの要件を考慮して、我々は 2 種類の熱電 対を候補として検討した。一つは、ロジウム $13 \%$ を含む 白金ロジウム合金と純粋な白金とを素線に用いた熱電対 $(\mathrm{R}$ 熱電対) であり、もう一つは純粋な白金と純粋なパラジウ ムを素線に用いた熱電対 (白金パラジウム熱電対 : $\mathrm{Pt} / \mathrm{Pd}$ 熱電対)である。どちらも高温が計測できる熱電対である。 $\mathrm{R}$ 熱電対は従来から広く用いられているものであるが、高 温での安定性にやや難点がある。白金パラジウム熱電対は 最近新たに開発された熱電対で、安定性は $\mathrm{R}$ 熱電対より も良いと期待されるが、まだ使用実績がそしく、安定性な どの特性が十分に把握されるまでに至っていないものであ る。

校正事業者は産総研で校正された仲介標準器を受け 取って、自社の害用標準器に温度の標準值を移すことにな る。我が国では校正事業者の多くが自社の実用標準器とし て温度定点実現装置を持っている。この場合校正事業者 は自社の温度定点実現装置を使って、一般の熱電対に対し て校正サービスを行う。

\section{2 シナリオの設定}

産総研としてはまず、仲介標準器として何を選択し、ど の温度定点を使って校正サービスを行うかのシナリオを二 つの観点から検討した。計量標準の設定方法は、世界各 国の国立標準研究機関が研究開発を競い、新たな方法が 提案されたり、これまでの方法の評価や改良が行われたり している。これらの成果を積極的に取り入れ、質の高い計 量標準を設定し、それを出発点とした標準体系を作ること が理想的である。一方、標準の受け手である校正事業者 は、従来から使っている方法によって標準の供給を受ける 方が、自社の設備や校正手順がそのまま使える点で対応 が容易であると言える。この相反する二つの観点から、図 2 に示すような四つのシナリオを検討した。 
・仲介標準器としてR熱電対を用いる場合 シナリオ (1) : 産総研が三つの温度定点 (銀点、銅点、 パラジウム点)で1本のR熱電対を校正し、それぞれの 熱起電力の值 (校正值)に基づいて $960{ }^{\circ} \mathrm{C}$ から $1550{ }^{\circ} \mathrm{C}$ の間で温度と熱起電力の関係を数式の形で表し、この 数式を標準値として校正事業者に供給する。

シナリオ (2) : 産総研が 三つの温度定点 (銀点、銅 点、パラジウム点) で1本またはそれぞれ専用のR熱電 対を校正し、それらの熱起電力の值（校正值）を標準 值として校正事業者に供給する。

・仲介標準器として白金パラジウム熱電対とR熱電対を併 用する場合

シナリオ (3) : 産総研が二つの温度定点 (銀点、銅点) でそれぞれ専用の白金パラジウム熱電対を校正すると ともに、一つの温度定点 (パラジウム点) でR熱電対を 校正して、それらの熱起電力 (校正值)を標準值として 校正事業者に供給する。

・仲介標準器として白金パラジウム熱電対を用いる場合 シナリオ (4) : 産総研が四つの温度定点 (銀点、銅点、 コバルトー炭素共晶点用㱯3、パラジウムー炭素共晶点） でそれぞれ専用の白金パラジウム熱電対を校正して、 それらの熱起電力 (校正値) を標準値として校正事業 者に供給する。

これら四つのシナリオで重要なことは、仲介標準器に何 を選択するか、そしてどの温度を校正温度として選択する かである。四つのシナリオは、技術的には（1）から (4) の順に難しくなる。

シナリオ（1）では、産総研が校正事業者を経由せずに、 直接温度計のユーザーに校正サービスした方が効率的であ る。海外では、開発途上国の標準機関がしばしば選択す るシナリオであり、四つのシナリオの中では、校正の不確 かさが最も大きくなる。

シナリオ(2)は、仲介標準器を受け取る校正事業者にとっ

$\mathrm{Ag} \mathrm{Cu} \quad \mathrm{Co}-\mathrm{C} \quad \mathrm{Pd}-\mathrm{C} \quad \mathrm{Pd}$ $961.78^{\circ} \mathrm{C} 1084.62^{\circ} \mathrm{C} 1324.0^{\circ} \mathrm{C} 1491.9^{\circ} \mathrm{C} 1553.5^{\circ} \mathrm{C}$
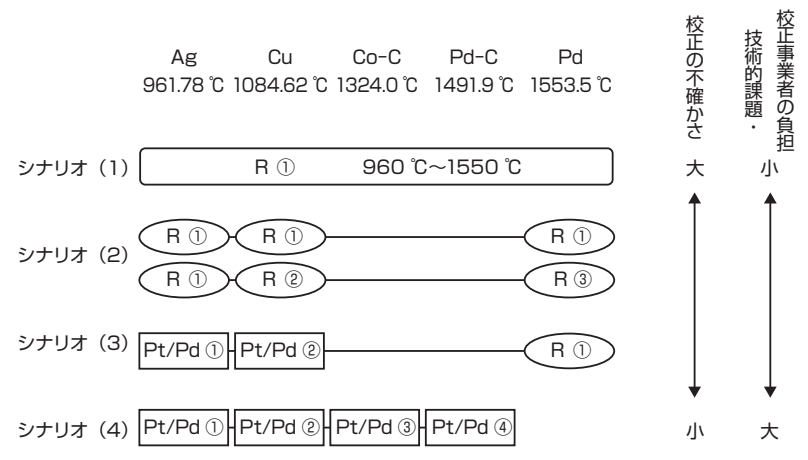

図 2 熱電対のトレーサビリティを実現するシナリオの比較 $\mathrm{R}$ および $\mathrm{Pt} / \mathrm{Pd}$ は仲介標準器としての $\mathrm{R}$ 熱電対および白金パラジウ 么熱電対を表し、丸囲み数字は個体の識別を示す。
ては、従来から習熟している機器を用いればよいので利用 しやすいものである。しかし、校正事業者が行う $1000{ }^{\circ} \mathrm{C}$ での $\mathrm{R}$ 熱電対の校正サービスの不確かさを例えば $0.3{ }^{\circ} \mathrm{C}$ と 想定した場合、自社の実用標準器にはその約 $1 / 3$ の大きさ の $0.1{ }^{\circ} \mathrm{C}$ の不確かさが必要になる。このシナリオでそれを 達成することは容易ではない。その理由は 4 章で詳述する が、仲介標準器として用いる $\mathrm{R}$ 熱電対の安定性に限界が あることによる。

シナリオ (4) は、最新の研究成果である金属一炭素共 晶点を国家計量標準に位置づけるもので、今後の研究の 進展も取り入れることができる発展性に優れた方法であ る。しかし、このシナリオによる標準の供給は、受け手の 校正事業者が新たな設備を導入し、新しい技術を習得し なければならないので負担が増加することになる。そこで 産総研は、シナリオ（4）を将来目指すべき理想としながら も、温度計の製造事業者や校正事業者の利用しやすい温 度定点を使うシナリオ (2) または (3) を現時点では選択し、 将来シナリオ (4) へ向かう準備をすることとした。

産総研は温度をはじめ種々の量の標準整備計画を 2001 年から順次公表・更新している。それはどのような国家計 量標準がいつ頃整備されるかを明示しているので、産業界 側は校正事業に必要な設備や要員をあらかじめ準備し、国 家計量標準の供給時期に合わせて校正事業を開始するこ とができる。産総研は標準整備計画で、銀点と銅点を用い た熱電対の校正サービスの開始時期を 2002 年と公表し、 それまでの期間を利用して、仲介標準器について検討し た。温度関連の学術団体や工業会の研究会がほぼ毎月開 催され、産総研における標準開発の状況を報告し、各校 正事業者や温度計の製造事業者における温度計校正技術 の現状などを議論しつつ、銀点と銅点での仲介標準器の 校正について産総研で取得した技術デー夕を示した。

このような情報交換と意見交換を繰り返して、産総研と 産業界との間で次のような合意が形成された。 $\mathrm{R}$ 熱電対を 仲介標準器とすることは安易な選択ではあるが、熱電対の 不均質による不確かさが大きくなる (4.2.1 項で詳述)。温 度計の製造事業者からの要望は、IEC 規格に定められた クラス 1 の熱電対の製品保証に足る十分小さな不確かさで あった。国家計量標準の整備のタイミングに合わせて、不 確かさの小さい仲介標準器を開発し普及させることができ れば、大きな利点となることが認識された。この研究開発 の詳細は 4.2 節で述べるが、 $0.1{ }^{\circ} \mathrm{C}$ 程度の小さな不確かさ が得られる技術的見通しが得られたことから、銀点、銅点 に対しては、白金パラジウム熱電対を仲介標準器とするシ ナリオ（3）を採ることとした。

\section{3 要素の選択}


決定した方針は、産業界に早期に高度な標準を供給する ためにシナリオ（3）を採り、将来の高度化に向ってシナリ オ（4）に進んでいくものである。このために産総研にとっ て必要な要素として次の(1)から(6)を選んだ。

(1)高温度の国家計量標準である温度定点実現装置の製 作とその不確かさの評価

(2)仲介標準器としての白金パラジウム熱電対の安定化技 術の開発

(3)仲介標準器を温度定点で校正する技術と、その不確か さの評価

(4)国際比較による国家計量標準の同等性の確認

(5)定常的な校正サービスを確実に行うための品質システム の構築と運用

(6)合理的なトレーサビリティ体系の設計と技術文書の作成 これらの要素を統合·構成して、高温度のトレーサビリティ 体系を構築することを試みた。

上記の要素のうち(1)は、国家計量標準としての温度定点 の設定に関するものである。銀の凝固点 $\left(961.78{ }^{\circ} \mathrm{C}\right) 、$ 銅

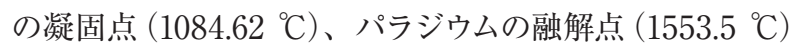
の三つをシナリオ (3) の実現のための国家計量標準として 開発した。さらに、将来シナリオ (4) に向かうための新た な国家計量標準としてコバルト-炭素共晶点 $\left(1324.0{ }^{\circ} \mathrm{C}\right)$ とパラジウムー炭素共晶点 $\left(1491.9{ }^{\circ} \mathrm{C}\right)$ を選択し、順次研 究を開始した。各温度定点における熱電対の熱起電力を標 準值として校正事業者に供給するために、パラジウムの融 解点での仲介標準器は、 $\mathrm{R}$ 熱電対を選択した。一方 1500 ${ }^{\circ} \mathrm{C}$ 以下の温度においては、白金パラジウム熱電対を仲介標 準器に選択した。要素(2)は、この白金パラジウム熱電対の 開発である。

要素(3は、実際に整備された温度定点実現装置を用い て、仲介標準器を校正するための技術と校正の不確かさの 評価である。要素(4)は海外の国立標準研究機関との標準 の比較に関するものであり、国家計量標準と校正技術の国 際同等性を確認するために行った。国際比較を行うための 仕組みが国際的に定められているが、この国際比較は、 アジア太平洋地域内に組織されたアジア太平洋計量計画 (Asia Pacific Metrology Programme、以下 $\lceil A P M P 」$ という。）という国際組織において 12 機関が参加して行わ れたものである。

要素5は、確立した国家計量標準による校正サービスを 産総研が定常的かつ確実に行うための体制の整備とその 運用についてである。要素6は、整備された計量標準が 校正事業者に利用されて、産業界が用いる温度計を校正す るまでの温度標準のトレーサビリティの体系についてであ る。校正事業者の技術レベルを第三者が認定するための
基準となる技術文書の作成も重要な要素である。この文書 に基づき、校正事業者の校正能力が確認される。

要素(1)から(5)の内容はそれぞれ次章の) 4.1 節から 4.5 節 で述べ、要素6の内容は 5 章で述べる。

\section{4 国家計量標準の整備と仲介標準器の開発 4.1 温度定点実現装置の製作と評価}

温度定点を実現する方法には、るつぼ中に鋳込んだ金 属を融解・凝固させ、その融解点または凝固点の温度を実 現する方法 (るつぼ法) と、校正する熱電対の測温接点近 くに定点物質の金属線を直接取り付けて融解点の温度を実 現する方法 (ワイヤ法) がある。るつぼ法は定点温度の再 現性が良く、また長時間定点の温度を持続できるので温度 定点を精密に実現するのに一般的に用いられている方法で ある。ワイヤ法は定点物質を融解するためのるつぼが不要 なため実現が簡易であり、また $0.1 \mathrm{~g}$ 以下のわずかな量の 定点物質で校正が可能である。ワイヤ法はるつぼ材料が 定点物質を污染することが懸念される場合や、貴金属のよ うな高融解点の純金属を用いる定点校正に一般的に用いら れている。産総研が熱電対の校正サービスを開始するにあ たり、銀点、銅点、コバルトー炭素共晶点の実現には再現 性の良い凝固点温度を持続できるるつぼ法を採用し、パラ ジウム点の実現にはパラジウムを定点物質とするワイヤ法を 採用した。

\subsection{1 銀点実現装置}

銀点実現装置の概念断面図を図 3 に示す。定点装置は 大きく分けて、ヒーターと制御系から成る「定点炉」およ び定点物質を含む「定点セル」から構成される。定点炉に は密封型のナトリウムヒートパイプで温度の均一化を図っ

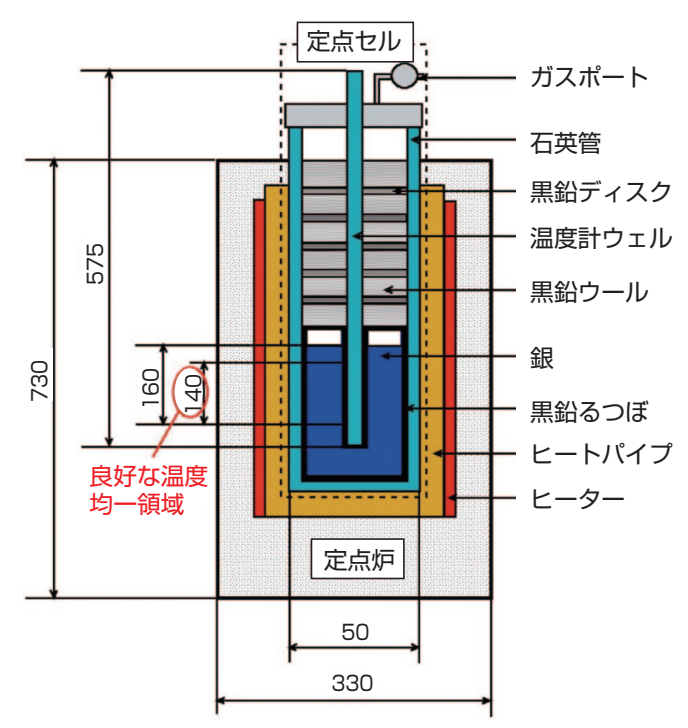

図 3 銀点実現装置の模式図 
た縦型電気炉を使用し、960 ${ }^{\circ} \mathrm{C}$ 付近で 9 時間にわたり $25 \mathrm{mK}$ 以内の高い温度安定性と、高さ $14 \mathrm{~cm}$ にわたり土 $6 \mathrm{mK}$ 以内の良好な温度均一性とを実現した。定点セルは、 銀に加わる気体の圧力を測定できるオープン型とし、公称 純度 $99.9999 \%$ の銀を黒鉛製のるつぼの中に $1390 \mathrm{~g}$ 封入 した。凝固点の温度は土 $10 \mathrm{mK}$ の範囲で 5 時間持続する ことが可能であり、再現性は 14 回測定して標準偏差が 3.8 $\mathrm{mK}$ であった ${ }^{[2]}$ 。この装置を使用することにより、銀点に おいて $0.09{ }^{\circ} \mathrm{C}$ の拡張不確かさ（約 $95 \%$ の信頼の水準） で熱電対を校正できると評価した。

\subsection{2 銅点実現装置}

銅点実現装置の概念断面図を図 4 に示す。この装置は 前述の銀点実現装置と同様、ヒーターと制御系から成る「定 点炉、および定点物質を含む「定点セル」から構成される。 定点炉は縦型とし、高さ方向に 3 分割したゾーンのそれぞ れに発熱体を独立に設置して温度制御する電気炉とした。 発熱体には無誘導巻のカンタル線を使用し、制御用熱電対 として R 熱電対を各ゾーンの中央部に設置した。定点炉の 設計において、従来の一般的な 3 ゾーン電気炉と比べて異 なるのは、制御用熱電対と発熱体の熱接触を良くした点、 断熱材を厚くして炉の保温性を向上させた点である。制御 用熱電対はアルミナ管を介して発熱体と接触させて応答性 を良くし、炬の温度制御性を向上させた。また、発熱体の 周りの断熱材には高温用耐火繊維 (セラミックファイバー) を用い、150 mm 以上の厚さにして炉の保温性を向上させ た。これにより、消費電力は $1 \mathrm{~kW}$ 以下に抑えることがで きた。定点セルは、銀点と同様のオープン型とし、公称

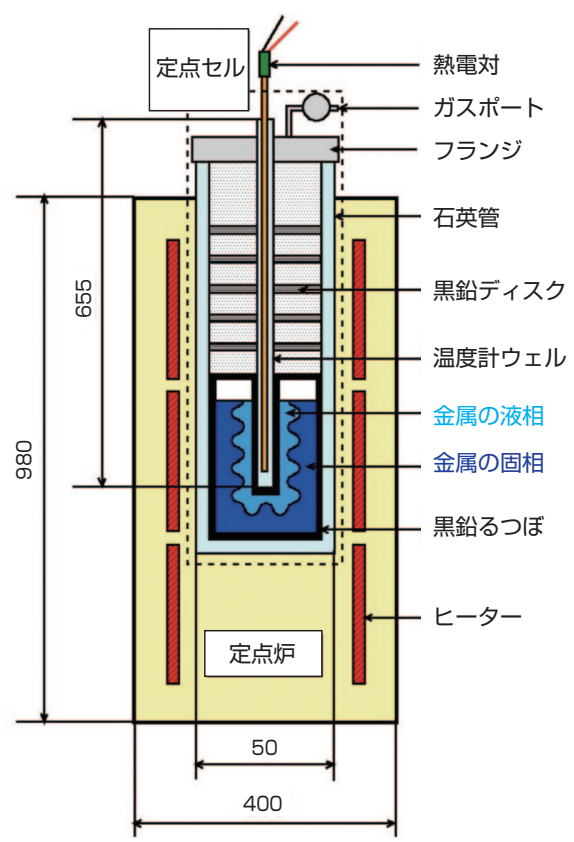

図 4 銅点実現装置の模式図
純度 $99.9999 \%$ の銅を黒鉛製のるつぼ中に $1450 \mathrm{~g}$ 封入し た。図 5 は銅が凝固する時の定点セル内の温度の時間変 化を示したものである。凝固点の温度は土 $2 \mathrm{mK}$ の範囲で 8 時間持続した。融解・凝固を 26 回繰り返して測定した凝

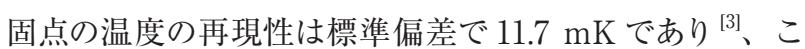
の装置を使用することにより、銅点において $0.11{ }^{\circ} \mathrm{C}$ の拡張 不確かさ (約 $95 \%$ の信頼の水準) で熱電対を校正できる と評価した。

\subsection{3 コバルト一炭素共晶点実現装置}

るつぼ法で $1100{ }^{\circ} \mathrm{C}$ 以上の温度定点がこれまで実用化さ れなかった大きな理由には、融解点・凝固点測定のために 純金属を黒鉛製のるつぼで保持した場合、るつぼの構成 元素である炭素が高温下で純金属中に溶け出し、純金属 を炭素で污染して融解点を降下させてしまうことが挙げら れる。この問題を解決する方法として、金属と炭素をあら かじめ共晶合金の組成の比率で混合して黒鉛製のるつぼ 中に保持することが発案された。これにより、るつぼ法で 再現性の良い融解温度が実現でき、温度定点として利用 可能になった ${ }^{[4]}$ 。金属一炭素共晶点は高温領域の新しい温 度定点として世界の先進的な国立標準研究所で現在研究 が進められている。この技術を用いて熱電対を校正するた めのコバルトー炭素共晶点実現装置を開発し、それまで作 製が困難であった大型のコバルトー炭素共晶点セルの作製 に世界に先駆けて成功し、熱電対の校正に使用できること を実証した ${ }^{[5]}$ 。装置の設計においては、銅点実現装置の 技術を応用した。ただし、銅点実現装置ではるつぼを保 持するのに石英管を使用したが、コバルトー炭素共晶点の 温度では石英の失透もしくは軟化が起こるため、石英管の 代わりにアルミナ管を使用した。

図 6 はコバルトー炭素共晶点の融解・凝固曲線を示した ものである。不確かさ評価の結果、コバルトー炭素共晶点 において $0.53{ }^{\circ} \mathrm{C}$ の拡張不確かさ(約 $95 \%$ の信頼の水準)

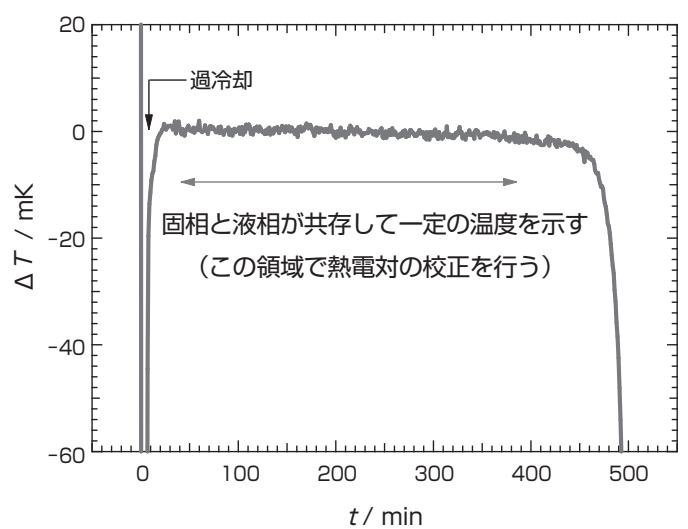

図 5 銅点での凝固曲線 
で熱電対を校正できることがわかった ${ }^{[6][7]}$

\subsection{4 パラジウム点実現装置}

パラジウムの融解点を実現するためにワイヤ法を選択す ることは前に述べたが、熱電対への定点物質の取り付け方 には幾つかの手法がある。実験的な評価の結果、図 7 の ようにコイル状のパラジウム線を取り付ける手法が安定した 融解温度を実現するのに効果的であることがわかった ${ }^{[8]}$ 。 図 8 は、コイル状のパラジウム線を取り付けた $\mathrm{R}$ 熱電対を パラジウム点実現装置に扱入した後、徐々に炉の温度を上 昇させたときの $\mathrm{R}$ 熱電対の熱起電力の時間変化を示す。 取り付けたパラジウム線の溶融に伴って 150 秒間でェ 0.05 ${ }^{\circ} \mathrm{C}$ の範囲で融解温度の持続が観測され、この領域の熱起 電力の平均值をもってパラジウム点での被校正熱電対の熱 起電力の校正值とした。測定の結果、約 $0.05{ }^{\circ} \mathrm{C}$ の再現性 (標準偏差) で融解温度が実現できることが確認された。 この装置を用いることにより、パラジウムの融解点において $0.79{ }^{\circ} \mathrm{C}$ の拡張不確かさ (約 $95 \%$ の信頼の水準) で熱電対 を校正できた。

\section{2 白金パラジウム熱電対の安定化技術}

\subsection{1熱電対のドリフトと不均質}

温度定点から熱電対に温度の標準值を移すときに最も 大きな不確かさの要因となるのが熱電対自身の安定性であ

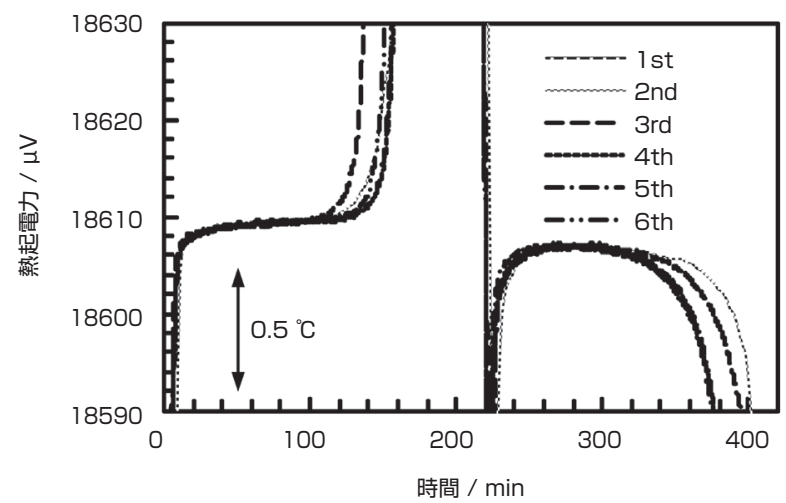

図 6 コバルトー炭素共晶点での融解・凝固曲線

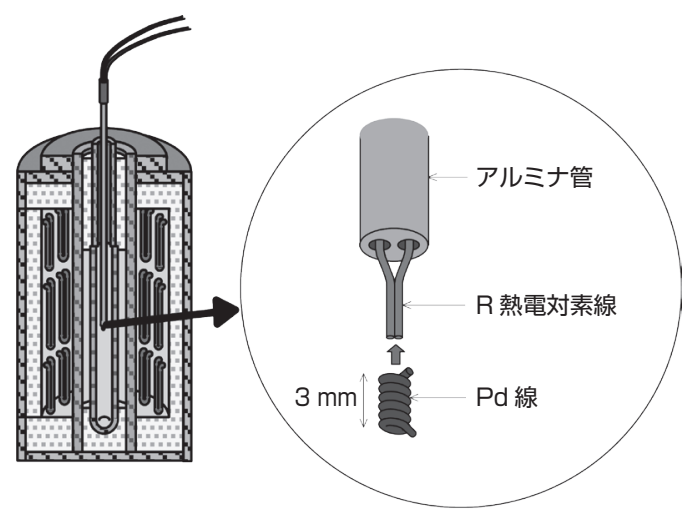

図 7 パラジウムの融解点実現のためのワイヤ法
る。図 9 は、高温の炉中に新品の熱電対を挿入し、挿入 長を固定したまま測温接点を長い時間高温に曝露した場 合、熱電対の特性が時間の経過に伴いどのように変化する のかを模式的に示している。 $S$ はゼーベック係数と呼ばれ る熱電対の特性であり、ここでは簡単のために $S$ は温度 依存性をもたないと仮定して説明する。図中の $E$ は温度勾 配域で素線に発生した電場を示しており、Eを熱電対の素 線に沿って積分したものが実際に観測される熱起電力とな る。また $E$ と $S$ には、 $E=S d T / d x$ の関係がある ${ }^{[9[110]}$ 。こ こで $x$ は熱電対の素線に沿った位置座標である。

新品の熱電対を炉中に挿入すると、最初は図 9 (c) の実 線に示されているように、ゼーベック係数 $S$ は位置 $x$ によ らず一定の值を示す (これを均質であると言う)。この熱電 対の扦入長を固定したまま、測温接点を高温に曝露し続け ると、図 9 (c) の点線で示したように、高温に曝露された 部分でのゼーベック係数が、熱電対素線の組成変化や構 造変化などに起因して次第に変化し、場所によって一様で はなくなる。こうしたゼーベック係数 $S$ の変化に伴い、図 9 (d) に示すように電場 $E$ も変化し、結果として熱起電力 の変化が観測される。このように、熱電対の位置を固定し たまま測温接点を高温に曝露するとドリフトと呼ばれる熱 起電力の変化が観測される。この熱起電力の変化の傾向 と大きさは熱電対の種類によって大きく異なる。

測温接点と基準接点の温度をそれぞれ一定とした場 合、図 9 (c) で示した新品の熱電対のように、ゼーベック 係数 $S$ が均質な熱電対では熱起電力は測温接点と基準接 点の温度のみで決まるため、温度勾配が素線のどの位置 にかからうとも挿入深さによらずに熱起電力は同じ值を示 す。一方、炉内で長い時間高温に曝露してドリフトが観測 された熱電対では、眓 10 のように熱電対の拥入長を変化 させると熱起電力が変化する。この熱電対のように素線の 位置によってゼーベック係数が異なる熱電対を一般的に「不

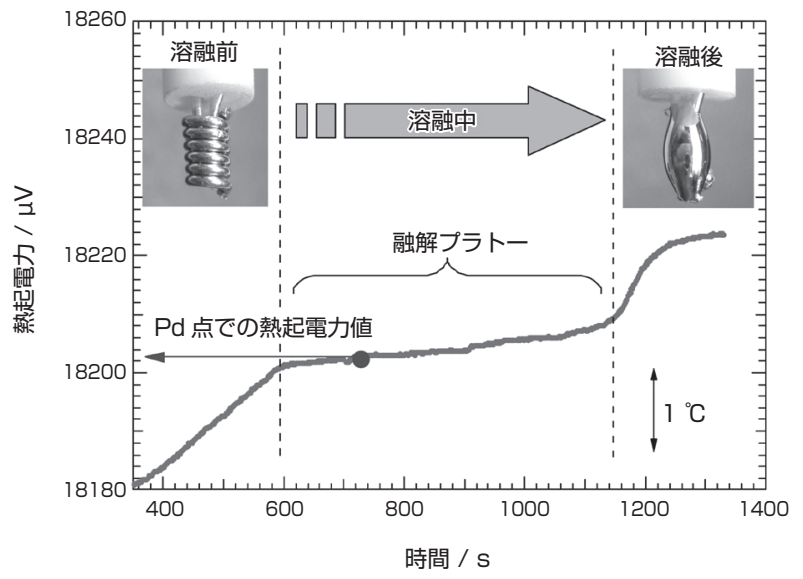

図 8 パラジウム点での融解曲線 
均質な熱電対」と呼ぶ。実際の温度測定では、熱電対の 挿入長を変えるなどして、温度勾配がかかる位置を変化さ せたときに生じる熱起電力の変化量を「不均質」と呼ぶこ とが多い。不均質な熱電対では測温接点と基準接点のそ れぞれの温度值のみで熱起電力は決まらず、炉の温度分布 に依存するため、校正された仲介標準器であっても異なる 温度分布で使用すれば、不均質は誤った標準值を与えるこ ととなる。一般の熱電対のゼーベック係数 $S$ は温度依存性 を持つが、同様の考え方が成り立つ。

\subsection{2 ドリフト・不均質の評価方法の確立}

前述のように熱電対のドリフトと不均質は仲介標準器の 安定性を評価するうえで非常に重要な項目となる。特に高 温域では一般にドリフトと不均質は大きくなる傾向があるた め、これらは熱電対の校正の不確かさの大きな要因となる。

熱電対の安定性の評価を行うにあたり、当初、米国立 標準技術研究所 NIST とイタリア国立標準研究所 IMGC が合同で研究した報告書 ${ }^{[1]}$ を参考にして作製した白金パ ラジウム熱電対のドリフトと不均質を調べた。熱処理は NIST-IMGC の研究とほほ同様に、熱電対素線への直接

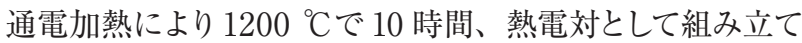
た後、炉中にて $1100{ }^{\circ} \mathrm{C} て ゙ ~ 3$ 時間、その後、 $450{ }^{\circ} \mathrm{C} て ゙ 10$

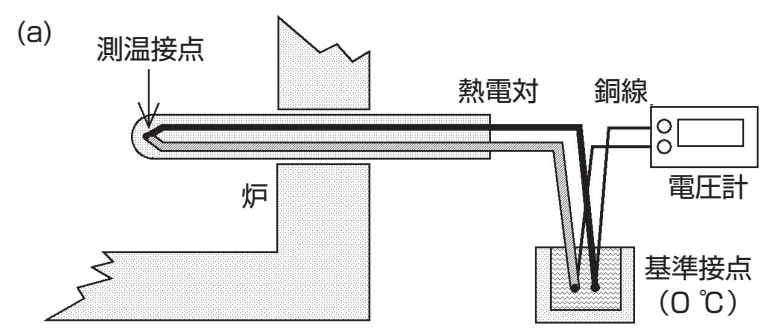

(b)

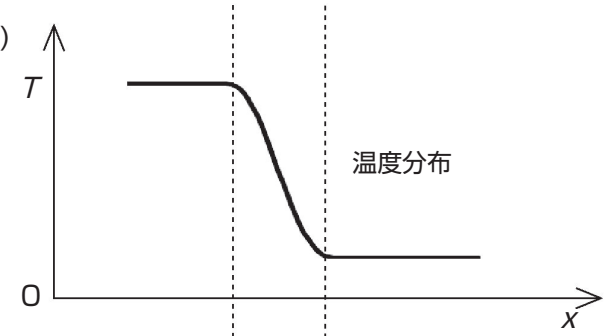

(c)

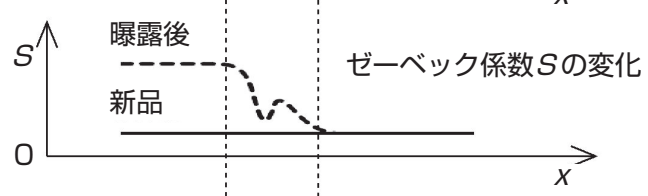

(d)

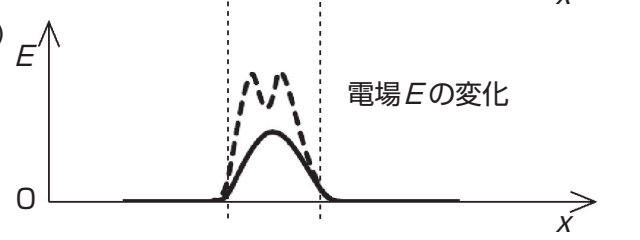

図 9 熱電対の高温嚗露による熱起電力の変化 実線は新品時の、点線は高温に曝露した後の熱電対のゼーベック係 数と電場を示す。
時間行った。

熱電対の測温接点を一定の温度に保つために銅点実現 装置を使用し、定点実現装置の凝固温度の安定性と均熱 性を利用して、熱電対のドリフトと不均質を同時に測定す る方法をとった ${ }^{[12]}$ 。熱電対の測温接点を銅点実現装置の 測温孔の最深部から $1 \mathrm{~cm}$ 上の位置まで挿入し、そのまま の状態で銅の凝固と融解を繰り返し実現させて、熱起電 力の変化の様子をモニターした。このとき銅点実現装置は 絶えず融解と凝固を繰り返すよう温度制御がプログラムさ れており、熱電対の測温接点は常に銅点温度に曝露されて いる。測温接点の位置を固定し、ドリフトを約 500 時間測 定した結果が図 11 である。白金パラジウム熱電対の熱起 電力は曝露開始後最初の 50 時間まで大きく変化しており、

(a)

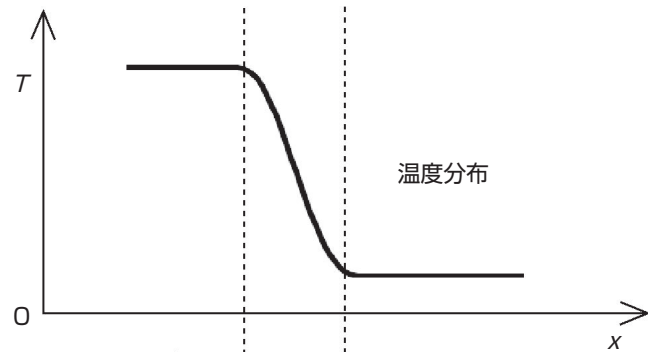

(b)

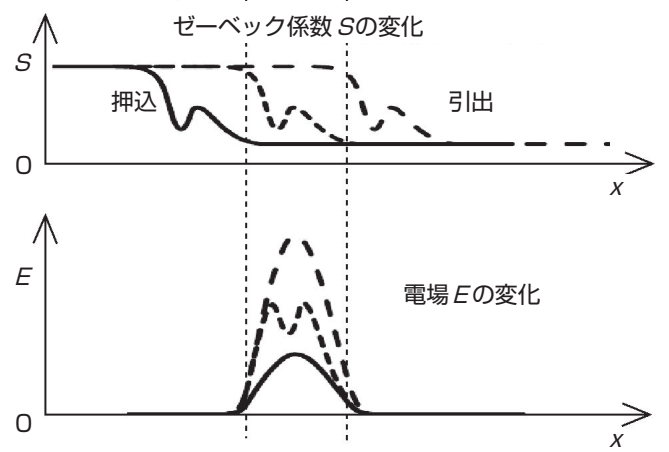

図 10 熱電対の高温炕への扱入長を変化させた場合の熱起電 力の変化

実線は高温に曝露された熱電対を押し达んでいった時、破線は引き 出した時のゼーベック係数と電場を示す。

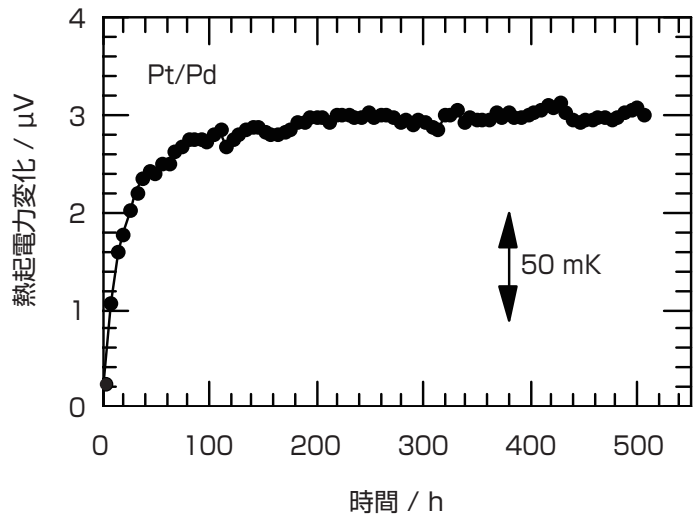

図 11 銅点に嚗露した場合の白金パラジウム熱電対のドリフト 
100 時間以降はほぼ一定の値を示した。

図 12 は、ドリフト測定の途中で銅の凝固が進行中に熱 電対を上下に移動させたときの熱起電力の変化をプロット したものである。ドリフトの測定を行うときの測温接点の 位置を基準点 $(0 \mathrm{~cm})$ とした。図中の $0 \mathrm{~h} \sim 505 \mathrm{~h}$ は、曝 露開始からの経過時間である。曝露開始時 $(0 \mathrm{~h})$ のデー 夕は、熱電対を $0.5 \mathrm{~cm} / \mathrm{min}$ の速度で下方に挿入しながら 熱起電力変化を測定したものであり、その他のデー夕は図 中に記した経過時間の時に熱電対を $0.5 \mathrm{~cm} / \mathrm{min}$ の速度で 上方に引き上げながら測定したものである。図 12 のデー夕 を得るために行った「熱電対の挿入長を変える」行為は、 測温接点の温度を同じに保ったまま「熱電対の素線に沿っ た温度分布を変える」行為と同等であり、この時の熱起電 力の変化は熱電対の不均質を反映している。熱電対の不 均質を定量的に評価するため、ここでは、図 12 の $7 \mathrm{~h} の$ 例のように、 $0 \mathrm{~cm}$ から上方 $8 \mathrm{~cm}$ までの熱起電力の変化を 熱電対の「不均質」と定義した。

この方法を用いて、温度定点での熱電対の安定性をほぼ 自動運転で大量に評価することができるようになり、これ により次節で述べる安定な仲介標準器の開発・評価を効 率的に行うことが可能になった。

\subsection{3 安定な熱電対の作製方法}

白金パラジウム熱電対は純金属である白金線とパラジウ ム線を素線として構成されているが、不均質に起因する熱 起電力の変化は主にパラジウム線が関係していると報告さ

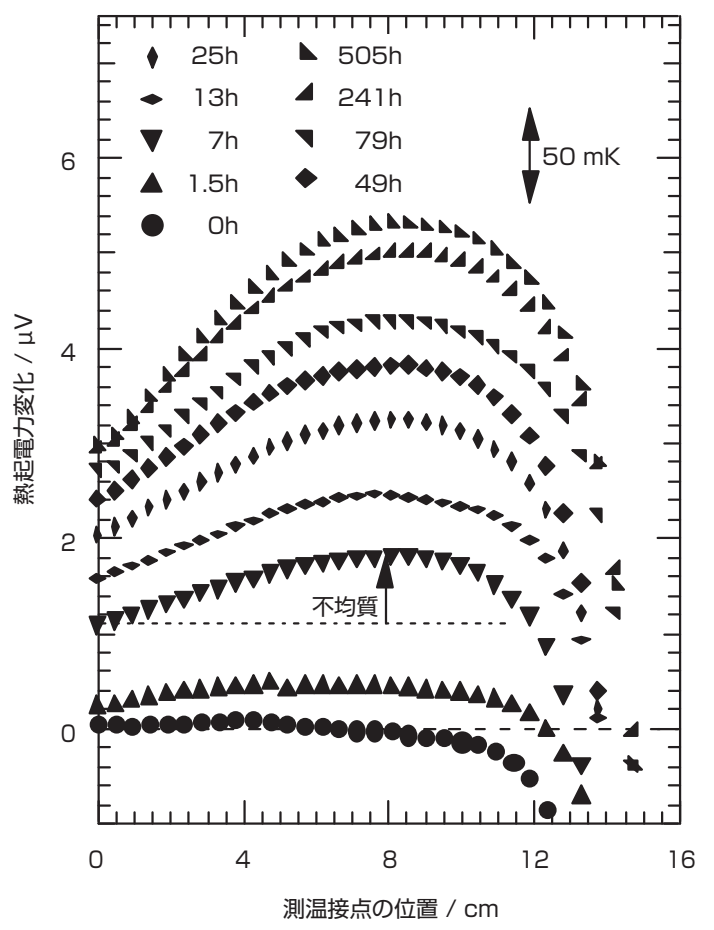

図 12 銅点に曝露した場合の白金パラジウム熱電対の不均質
れている ${ }^{[13]}$ そこで、パラジウム素線のロットの違いによ る影響を調べるため、公称純度は同じ 99.99 \%であるが、 ロットが異なる 4 種類のパラジウム線を用いて 4 本の白金 パラジウム熱電対を作製した ${ }^{[14]}$ 。ここで、作製した 4 本の 熱電対をそれぞれTC-a、TC-b、TC-c、TC-d と呼ぶこと にする。4 種類の異なるロットのパラジウム線の中で TC-a と TC-b のパラジウム線は同じ素線製造会社にて同じ製造 工程で作製されたものである。一方、TC-cと TC-d のパラ ジウム線は TC-a、TC-b と異なる別々の製造会社から購入 したものである。素線の通電加熱は $1200{ }^{\circ} \mathrm{C} て ゙ 10$ 時間行

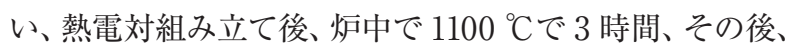
$450{ }^{\circ} \mathrm{C} て ゙ 10$ 時間熱処理を行った。

図 13 と図 14 はそれぞれこれらの熱電対のドリフトと不 均質の測定結果である。TC-a、TC-bのように、同じ素線 製造会社で同じ製造工程で作製されたパラジウム素線を使 用しても、ロットが異なればドリフトと不均質の変化の様子 は異なっていることが分かる。一方で、TC-d はドリフト、 不均質ともに小さい。このことは、適切なパラジウム素線

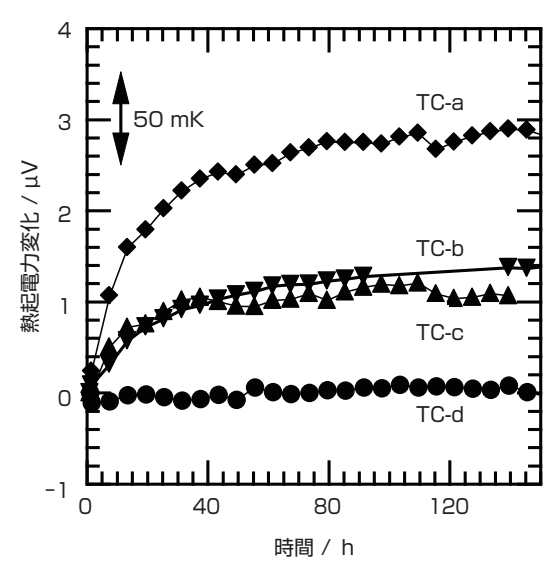

図 13 異なるロットのパラジウム素線を用いた白金パラジウム 熱電対のドリフト

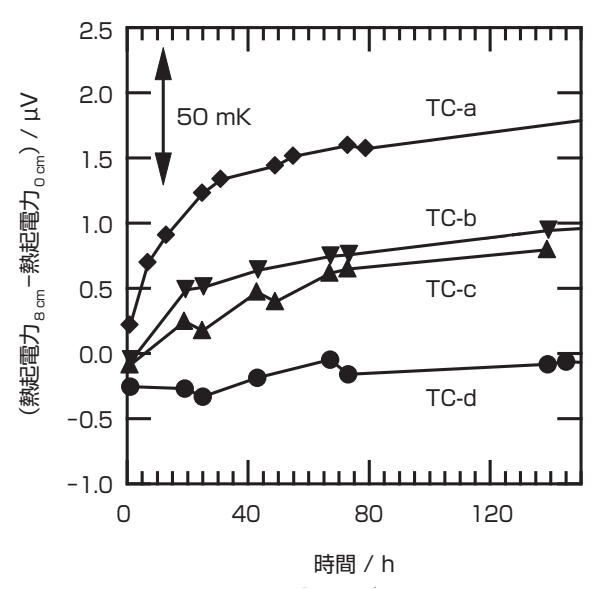

図 14 異なるロットのパラジウム素線を用いた白金パラジウム 熱電対の不均質 
のロットを選択すれば、ドリフトと不均質を大幅に減少さ せることができることを示唆する。ただし、TC-d で使用さ れているような素線を常に得ることは容易ではない。その ため、TC-a、TC-b、TC-cで使用されているような比較的 取得しやすい素線を用いて、ドリフト、不均質を小さくする 手法を調べた。

炉中での熱処理は、熱電対が実際の使用前に受ける熱 履歴の最後の工程であることから、熱電対の特性に深く関 わることが予想される。そこで、素線の歪み除去のため炉

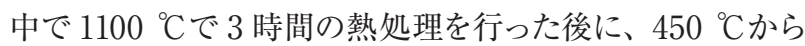
$1080{ }^{\circ} \mathrm{C}$ までの温度範囲の 1 点の温度で最終熱処理を施す ことにより、最終熱処理温度が異なる合計 11 本の熱電対 を作製した。これらの熱電対のパラジウム素線には最も大 きなドリフトを示した TC-a と同じロットのものを用いた。 また、図 11 での白金パラジウム熱電対の熱起電力が 100 時間でほほ安定していることから、最終熱処理の時間は 100 時間を選んだ。

図 15 は、上述のように作製した 11 本の白金パラジウム 熱電対に対して、銅点実現装置を用いて $1085{ }^{\circ} \mathrm{C}$ へ曝露し た場合の熱起電力のドリフトを示し、図 16 は同じくその不 均質を示す。図中に記す温度は最終熱处理温度である。

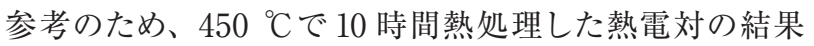
も黒丸でプロットしてある。どの熱電対も $1085{ }^{\circ} \mathrm{C} へ の$ 曝 露開始後 100 時間程で熱起電力は安定した。最終熱処理 温度が $730{ }^{\circ} \mathrm{C}$ のき、熱起電力は 100 時間で約 $4 \mu \mathrm{V}$ (約 $0.2 \mathrm{~K}$ に相当）と最大の変化を示した。ここで注目すべき

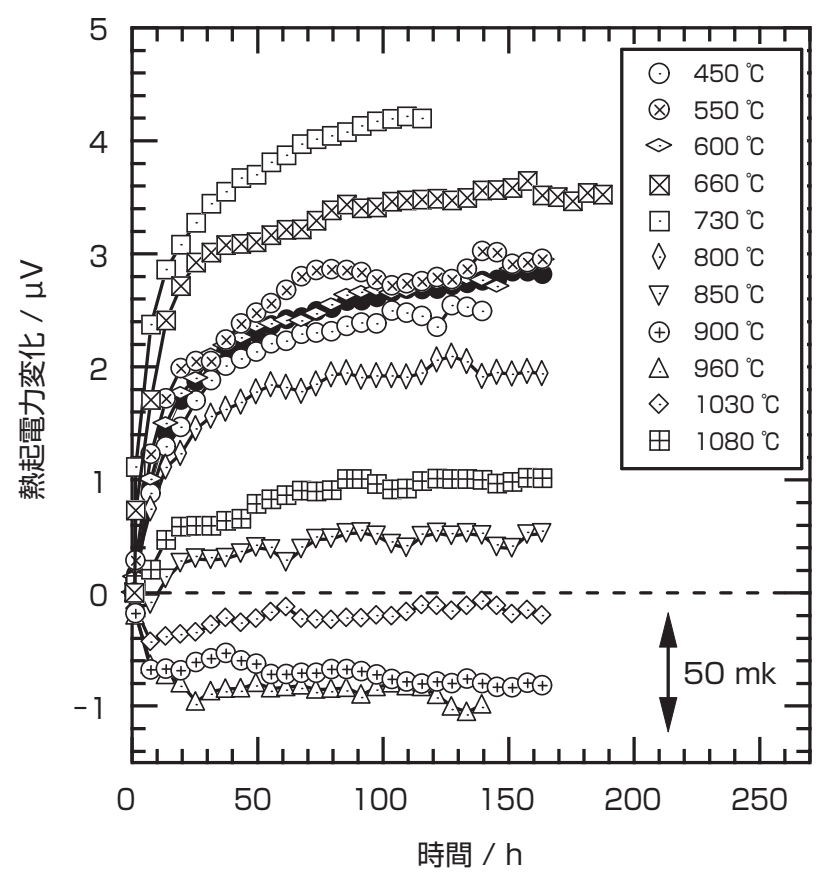

図 15 異なる最終熱処理温度に対する白金パラジウム熱電対 のドリフト

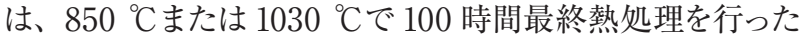
ものはドリフトと不均質がともに非常に小さくなっている点 である。熱起電力の変化は 150 時間にわたって $0.5 \mu \mathrm{V}(24$ $\mathrm{mK}$ に相当）以下となって扔り、この結果は、適切な熱処 理を行うことによって、白金パラジウム熱電対のドリフトと 不均質を抑えることができることを明らかにした ${ }^{[12] 。}$

銀点実現装置を用いた $962{ }^{\circ} \mathrm{C} へ の$ 曝露についても同様

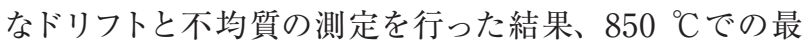
終熱処理の効果は素線のロットが異なっても有効である ことがわかった ${ }^{[15]}$ 。また、コバルトー炭素共晶点を用い た $1324{ }^{\circ} \mathrm{C}$ へ曝露についても同様の測定を行った結果、 $1030{ }^{\circ} \mathrm{C}$ での最終熱処理はコバルトー炭素共晶点でのドリ フトの低減に有効であることがわかった ${ }^{[16]}$ 。銀点より低い 温度への曝露では白金パラジウム熱電対のドリフトと不均 質は急速に小さくなった ${ }^{[17]}$ 。以上の結果は、適切な素線 と作製法、熱処理法を選択することによって、1330 ${ }^{\circ} \mathrm{C}$ ま゙ の温度で白金パラジウム熱電対のドリフトと不均質を非常 に小さくできることを意味する ${ }^{[16]}$ 。これにより、銀点、銅点、 およびコバルトー炭素共晶点の各温度でドリフトと不均質 を小さくし安定化させる手法を見い出すことができた。

\section{2 .4 白金パラジウム熱電対とR熱電対との比較}

$\mathrm{R}$ 熱電対の場合、 $1085{ }^{\circ} \mathrm{C}$ への曝露では熱起電力は単調 に減少し続けていく傾向を示し、300 時間曝露し続けた場 合 $0.2{ }^{\circ} \mathrm{C}$ 程度ドリフトした ${ }^{[9[114]}$ 。それに対して、図 15 で示 されたように、適切な最終熱処理を行った白金パラジウム 熱電対では、 $1085{ }^{\circ} \mathrm{C}$ の曝露を 150 時間行ってもドリフト

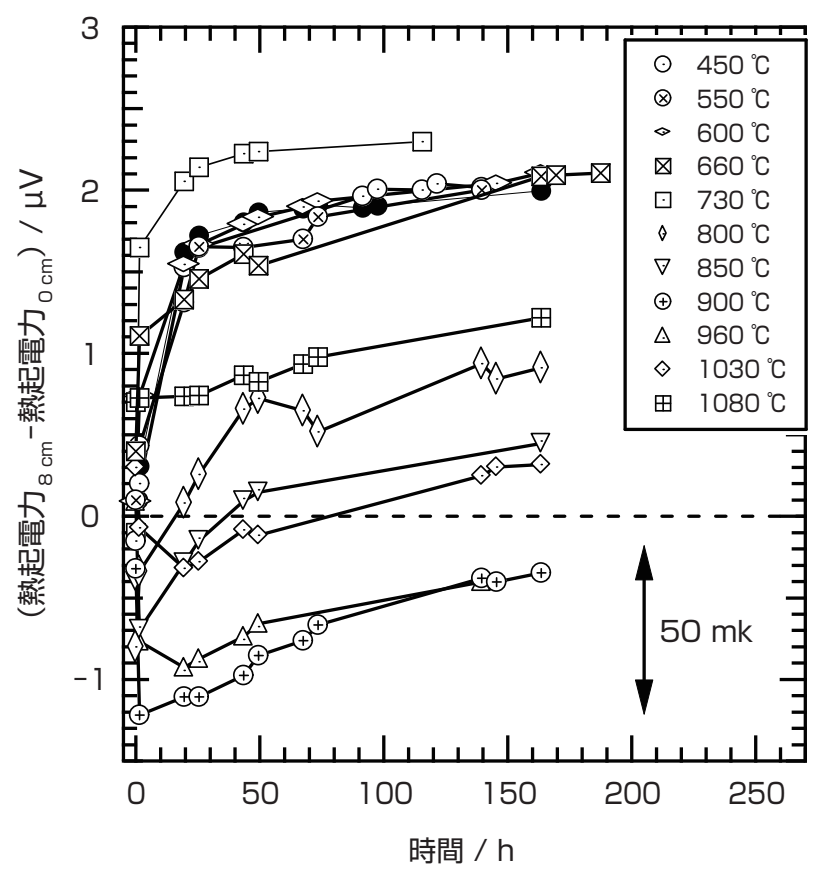

図 16 異なる最終熱処理温度に対する白金パラジウム熱電対 の不均質 
は $0.03{ }^{\circ} \mathrm{C}$ 以内に収まることがわかった。不均質についても ドリフト同様、 $\mathrm{R}$ 熱電対では単調に変化し続けていくのに 対し、適切な熱処理を行った白金パラジウム熱電対では、 図 16 で示されているように約 150 時間にて $0.04{ }^{\circ} \mathrm{C}$ 以内で ほぼ一定の値を示した。これらの明白な違いから、銀点、 銅点、コバルトー炭素共晶点では白金パラジウム熱電対を 仲介標準器として選択することを決めた。一方、白金パラ ジウム熱電対は素線にパラジウムを使用しているため、パ ラジウム点の温度では融解して使用できない。そのため、 パラジウム点の仲介標準器としては従来から使用実績に優 れ、国内で最も普及している R 熱電対を用いることとした。

\section{3 定点校正の不確かさの評価}

熱電対を仲介標準器として国家計量標準である温度定 点の標準値を供給する際、その不確かさの要因としては 様々なものがあるが、大きく分類すると「定点実現装置に 内在する不確かさ」、「熱電対を校正する時の測定系（電圧 計、基準接点装置など）に内在する不確かさ」、「校正対 象である熱電対自身のドリフトと不均質に起因する不確か さ」が考えられる。銀点、銅点、コバルト一炭素共晶点、 およびパラジウム点のそれぞれにおける熱電対の校正の不 確かさを表 1 に示す。拡張不確かさ（約 $95 \%$ の信頼の水 準）は銀点、銅点、コバルトー炭素共晶点、パラジウム点 でそれぞれ $0.09{ }^{\circ} \mathrm{C} 、 0.11{ }^{\circ} \mathrm{C} 、 0.53{ }^{\circ} \mathrm{C} 、 0.79{ }^{\circ} \mathrm{C}$ であり、次 節で示すように世界でトップレベルの高い校正能力となって いる。

\section{4 国際比較による国家計量標準の同等性}

実現した温度定点が他の国の国家計量標準と整合して いるかを検証するため、アジア太平洋地域の国立標準機 関の間での国際比較 (APMP-T-S1-04) が行われた。R 熱 電対を各参加機関に回送し、参加機関はそれを自己が保 有する温度定点で校正し、その校正值を幹事機関の校正 值と比較した。参加した国立標準機関はNMIA（オース トラリア)、NIM (中国)、SCL (香港)、NPLI (インド)、 KIMLIPI (インドネシア)、KRISS (韓国)、SIRIM (マレー

\section{表 1 各温度定点における熱電対の校正の不確かさ}

\begin{tabular}{|c|c|c|c|c|}
\hline 仲介標準器 & \multicolumn{3}{|c|}{ 白金パラジウム熱電対 } & R 熱電対 \\
\hline 校正に用いる温度定点 & 銀点 & 銅点 & $\begin{array}{l}\text { コバルト-炭素 } \\
\text { 共晶点 }\end{array}$ & パラジウム点 \\
\hline 定点の温度値 $/{ }^{\circ} \mathrm{C}$ & 961.78 & 1084.62 & 1324.0 & 1553.5 \\
\hline 測定系の不確かさ /C & 0.021 & 0.019 & 0.018 & 0.042 \\
\hline 定点実現装置の不確かさ $/{ }^{\circ} \mathrm{C}$ & 0.014 & 0.021 & 0.260 & 0.231 \\
\hline 熱電対自身の不確かさ /`C & 0.034 & 0.045 & 0.060 & 0.315 \\
\hline $\begin{array}{c}\text { 校正の合成標準不確かさ /̊C } \\
\text { (約 } 68 \text { \% \% の信頼の水準) }\end{array}$ & 0.042 & 0.054 & 0.267 & 0.393 \\
\hline $\begin{array}{l}\text { 校正の拡張不確かさ /̊C } \\
\text { (約 } 95 \text { \% の信頼の水準) }\end{array}$ & 0.09 & 0.11 & 0.53 & 0.79 \\
\hline
\end{tabular}

合成標準不確かさは、個々の不確かさ成分を合成したもので、各成分の不確かさの二乗和の正の平方根で 与えられる。
シア)、SPRING (シンガポール)、CSIR (南アフリカ)、産 総研 / NMIJ 、CMS (台湾)、およびNIMT (タイ) の 12 機関であった。

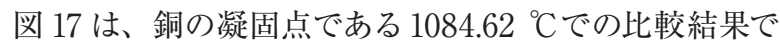
あり、各参加機関と幹事機関である NMIA との校正值の 差が各参加機関の校正の不確かさと一緒に示されている。 産総研 / NMIJ の校正の不確かさは参加機関の中でトップ レベルの小ささであり、銅点での校正值は各国が主張する 不確かさのレベルでほぼ一致することが確認された。

銀点での校正值の比較についても同じ国際比較の中で 行われており、銅点と同様に、産総研 / NMIJ の銀点での 校正の不確かさはトップレベルの小ささで、各国の校正值 はそれぞれが主張する不確かさのレベルでほぼ一致するこ とが確認された ${ }^{[18]}$ 。

コバルトー炭素共晶点については、欧州の主要な国立標 準機関である PTB (独)、NPL (英)、LNE (仏) が行っ ている共同プロジェクト Euromet project $857^{[19]}$ に産総研 /NMIJ も参加して、白金パラジウム熱電対とコバルトー炭 素共晶点セルを回送する国際比較を行った結果、良好な一 致を得ている ${ }^{[20]}$ 。

\section{5 熱電対校正の品質システムの構築と運用}

産総研が行う校正・試験サービスに関する品質システム に基づき、2004年に熱電対の校正業務に関する技術マニュ アルを作成した。校正・試験機関に関する国際規格である ISO/IEC 17025 の要求事項に適合するように、要員、施 設と環境条件、校正方法、設備、トレーサビリティ、校正 品目の取扱い、結果の報告などの各項目を規定し、それに

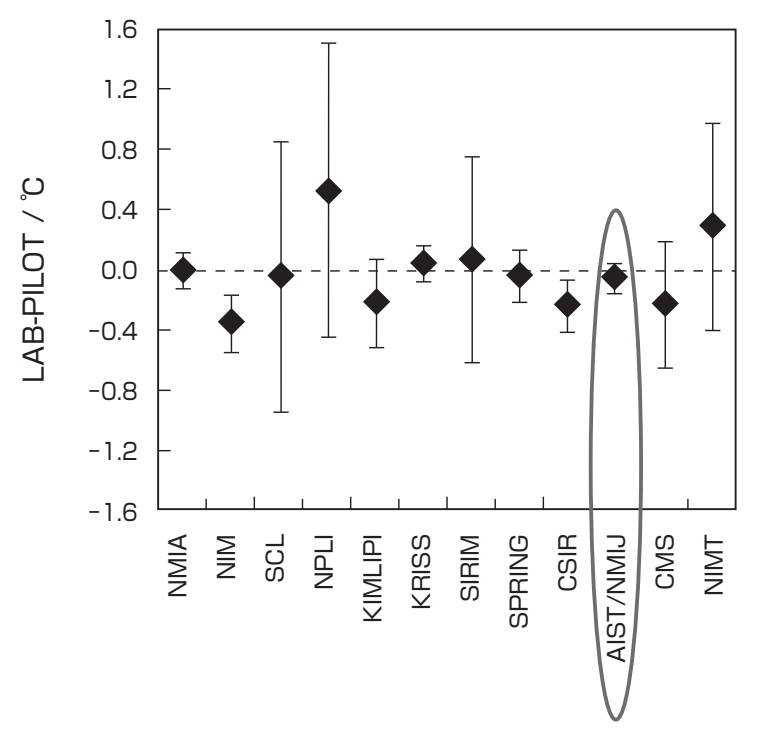

図 17 銅点 $\left(1084.62{ }^{\circ} \mathrm{C}\right)$ における $\mathrm{R}$ 熱電対の校正值の国際 比較の結果

けは各参加機関と NMIA との校正值の差を、誤差棒は各機関の校 正の不確かさを示す。 
従って校正を実施し、記録を保管するようにした。特に、 熱電対の校正に特有の不確かさの要因であるドリフトと不 均質についての評価方法を詳細に規定し、それらが熱電 対の校正值とその不確かさに与える影響を定量的に評価す る手順を技術マニュアルで定めた。2006 年 5 月には、独 立行政法人製品評価技術基盤機構が運営する認定プログ ラムのもとで産総研の熱電対の校正業務が国際規格に適 合すると認定された。慎重に不確かさの評価を行って熱電 対の校正方法を確立し、さらに国際比較によって検証した 技術を定常的に継続するために必要な要素が品質システム であり、産総研の行う熱電対の校正の信頼性を国内的・国 際的に高めている。

\section{5 トレーサビリティ体系の整備}

\section{1 熱電対のトレーサビリティ体系の設計}

国家計量標準が校正事業者に利用され、産業界が用い る温度計を校正するまでの温度のトレーサビリティの体系

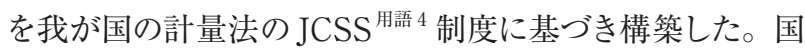
家計量標準として、産総研の銀点 (2002 年)、銅点 (2002 年)、パラジウム点 (2005 年) の各定点実現装置を計量法 で定める特定標準器に順次指定し、産総研からこれらの 3 点での校正值を仲介標準器に与えて標準値として校正事

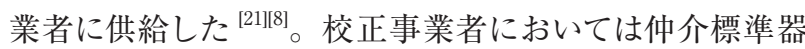
から自らが保有する温度定点装置に標準值を移した上で温 度目盛を作る方法を採用した。ただし、パラジウム点につ いては、実用標準熱電対へ比較校正により標準值を移す 方法も選択できることとした。

産総研が校正を行う仲介標準器は、計量法で定める特 定二次標準器に相当し、銀点と銅点では白金パラジウム熱 電対、パラジウム点では $\mathrm{R}$ 熱電対とした。熱電対を仲介標 準器としてパラジウム点の標準値の供給を開始したことによ り、図 18 に示すように、校正事業者は実用標準熱電対に 対して $1554{ }^{\circ} \mathrm{C}$ ま゙の温度標準を持つことが可能になり、 $\mathrm{R}$ 熱電対を始め各種の熱電対に対して、実用標準を用いた 校正ができることになった。現在、産総研では、特定標準 器による特定二次標準器の校正を年間 10 件程度行ってお り、それらに対して特定標準器による校正の結果であるこ とを示すため計量法に定められた「jcss」の標章を付けた 校正証明書を発行している。

jess 校正に加えて、産総研では依頼試験としてコバルト

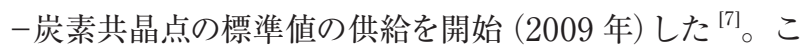
れにより、校正事業者が作った温度目盛のより正確な検証 が可能になった。

このようにして JCSS に登録した校正事業者は、例えば、 銅点までの各種の定点実現装置の校正、高温域について
は貴金属熱電対 $(\mathrm{R} 、 \mathrm{~S} 、 \mathrm{~B} 、 \mathrm{Pt} / \mathrm{Pd}) 、$ 卑金属熱電対 $(\mathrm{N} 、 \mathrm{~K} 、$ E、J、T) 拈よび指示計器付温度計の銅点までの定点校正、 最高 $1554{ }^{\circ} \mathrm{C}$ までの温度範囲での温度計の比較校正など、 自社の設備に合わせてさまざまな校正事業を柔軟に選択し て行えるようになった ${ }^{[22] 。 ~}$

\section{2 国内校正事業者との共同研究と技術文書の作成}

標準熱電対としての白金パラジウム熱電対の技術を普及 するために、日本学術振興会産業計測第 36 委員会温度計 測分科会の作業部会で 2001 年 6 月から 2002 年 3 月にか けて、白金パラジウム熱電対の持ち回り試験を行った。銅 点における校正作業に伴う熱電対のドリフトを評価すること を目的として、同一ロットから取った白金素線とパラジウム 素線から 4 本の白金パラジウム熱電対を同一条件で作製し て試験に供した。これらの熱電対を「産総研 $\rightarrow 4$ 事業者 ＼cjkstart産総研」と回送し、続いて回復アニールをした後に、再 び「産総研 $\rightarrow$ 残りの 4 事業者 $\rightarrow$ 産総研」と回送し、各事 業者での銅点校正作業によって校正值がどの程度変化する かを調べた。持ち回り試験に先立って、白金パラジウム熱 電対を作製するための熱電対素線や絶縁管などの材料仕 様条件、素線や絶縁管等の前処理および組み立て後の熱 処理などに関する組立条件、ならでに使用条件について、 各事業者の熱電対作製用設備および校正用設備、産総研 の校正用設備などの仕様をもとに検討を行った。

また、同作業部会では 2004 年に、産総研を含む 7 事 業者で「R 熱電対の Pd 点校正を含む共同実験」として、 2 種類の共同実験を行った ${ }^{[23-[25] 。}$

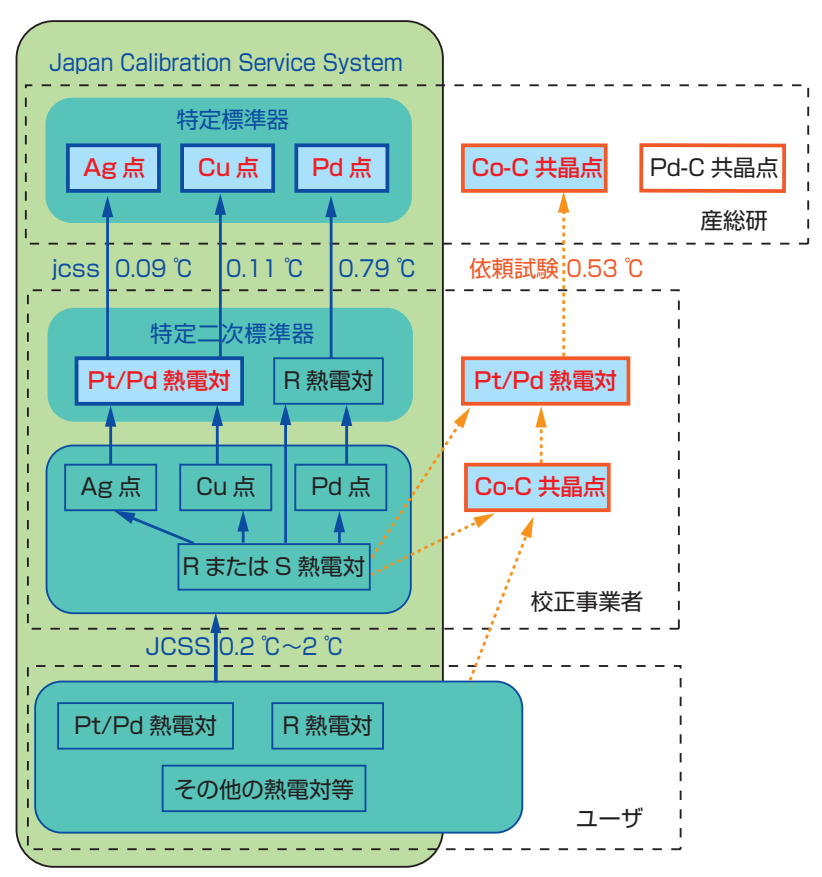

図 18 高温域における熱電対のトレーサビリティ体系図 $(2010$ 年 2 月時点) 
校正事業者がJCSS に登録されるためには、技術的要 求事項適用指針に適合することが要件になっている。こ の指針は、校正事業者に対する国際規格である ISO/IEC 17025 に規定されている技術的要求事項を明確化し、解釈 を示すものであり、独立行政法人製品評価技術基盤機構 が発行して公開している技術文書である。またこれは校正 事業者において校正が行われる際の技術能力を第三者が 認定するための技術基準ともなっている。この中の特定二 次標準器又は常用参照標準が具備すべき条件などは、上 記の共同実験の結果を踏まえて規定した。不均質の取り扱 いについての注意事項も多く記載された ${ }^{[26] 。}$

\section{6 標準整備の効果と今後の課題}

\section{1 熱電対のトレーサビリティ体系の整備による効果}

熱電対のトレーサビリテイ体系を構築したことによる現実 の効果として、我が国の JCSS 校正事業の温度範囲が拡 大し、さらには登録校正事業者が発行するJCSS 校正証 明書の件数が増加したことが挙げられる。JCSS 校正証明 書の発行件数は 2002 年度には約 2000 件 ${ }^{[27]}$ であったが、 2008 年度には約 10000 件 ${ }^{[28]}$ と 6 年間で約 5 倍となった。 温度計の製造事業者や校正事業者が出す規格適合証明や 校正值が、社会で広く使われている温度計の信頼性を確保 することに寄与している。

\section{2 白金パラジウム熱電対の産業界への普及}

本研究では、仲介標準器として開発した白金パラジウム 熱電対が、熱処理などを適切に行うことにより、極めて高 い性能をもつことを示した。この熱電対は当初産総研から 研究開発品として有料で頒布したが、頒布先は産総研に校 正を依頼する校正事業者のみに限定されていた。こうした 校正事業者以外のユーザーも広くこの白金パラジウム熱電 対を使えるように、この熱電対の作製法を民間企業へ技術 移転することを進めてきた。開発された白金パラジウム熱 電対は、作製方法の技術移転を行った株式会社チノーから 2006 年 4 月に販売が開始された ${ }^{[29]}$ 。

また、白金パラジウム熱電対は仲介標準器としてだけで なく、一般の温度計測用熱電対としての使用も期待され る。広く工業的な利用を促進させるため、産総研は IEC での標準化にも取り組み、2008 年に IEC 62460 として規 格化された ${ }^{[30]}$ 。

\section{3 パラジウムー炭素共晶点の開発}

3 章で述べたように、将来的には四つの温度定点 (銀 点、銅点、コバルトー炭素共晶点、パラジウムー炭素共晶 点）の標準值を、白金パラジウム熱電対を仲介標準器とし て供給することを目指している。そのために現在パラジウム 一炭素共晶点の開発とその評価を精力的に進めている ${ }^{[5]}$
コバルトー炭素共晶点と同様に共同プロジェクト (Euromet Project 857）に参加して欧州の代表的な国立標準研究所 PTB (独)、NPL (英)、LNE（仏）とパラジウムー炭素共 晶点の温度值の国際比較も行っており、熱電対を仲介標準 器とした標準供給の準備を着実に進めているところである。

表 2 に、パラジウムー炭素共晶点を含む各温度定点で の校正值の不確かさが、将来どの程度小さくなるか予想 を示す。現在、金属一炭素共晶点は 1990 年国際温度目盛 (ITS-90) 用棓5 の定義定点には採用されていない。そのた めに、熱電対用に製作したコバルトー炭素共晶点セルの温 度值は、ITS-90 に基づいて校正された放射温度計によっ て測定され、決められている。表 1 に示したコバルトー炭 素共晶点における熱電対の校正の不確かさの要因には「定 点実現装置の不確かさ」があり、0.26 ${ }^{\circ} \mathrm{C}$ と最も大きな不確 かさの要因となっている。そしてこの不確かさの要因の中 には、上述の放射温度計による測定の不確かさが含まれて いる ${ }^{[6]}$ 。今後、放射温度計による測定の不確かさがより小 さくなる見込みであり、その結果、コバルトー炭素共晶点 とパラジウムー炭素共晶点での熱電対校正の拡張不確かさ (約 $95 \%$ の信頼の水準) は $0.3{ }^{\circ} \mathrm{C}$ 程度になると予想され る。これが達成されると、白金パラジウム熱電対を仲介標 準器として、1500 ㅇでの温度域でより小さな不確かさで 標準供給が可能になる。

\section{7 おわりに一標準整備計画の意義}

1990 年代後半から、我が国の社会ニーズに基づいた標 準整備計画を策定し、それを基盤にしたトレーサビリティ 体系を整備してきたが、それらは当然のことながら、産業 界の動向と密接な関わりをもって実施されてきた。2001年 に開始した 10 年間の標準整備計画の実行は、現在終着点 が見えた段階にあるが、この間産総研がいつまでに、どの 計量標準を整備し供給するかを、校正事業者を始めとして 品質管理を重視する企業に明示して、我が国に最も適した 計量標準の体系を議論しながら構築してきた。すなわち、 それまで産業界が作り上げてきた信頼性確保のための技術 基盤と計量トレーサビリティを融合させる必要性を双方が 意識して活動してきた。

温度標準の場合は、産総研が供給する国家計量標準の

表 2 今後予想される各温度定点における白金パラジウム熱電 対の校正の不確かさ

\begin{tabular}{|c|c|c|c|c|}
\hline $\begin{array}{c}\text { 温度定点 } \\
\text { 定点の温度值 / }{ }^{\circ} \mathrm{C}\end{array}$ & $\begin{array}{c}\text { 銀点 } \\
961.78\end{array}$ & $\begin{array}{c}\text { 銅点 } \\
1084.62\end{array}$ & $\begin{array}{c}\text { コバルト- } \\
\text { 炭素共晶点 } \\
1324.0\end{array}$ & $\begin{array}{c}\text { パラジウム } \\
\text { 炭素共晶点 } \\
1491.9\end{array}$ \\
\hline $\begin{array}{l}\text { 校正の拡張不確かさ }{ }^{\circ} \mathrm{C} \\
\text { (約 95 \% の信頼の水準) }\end{array}$ & 0.09 & 0.11 & 0.3 & 0.3 \\
\hline
\end{tabular}


範囲拡大と民間事業者が行う校正事業の範囲拡大が歩調 を合わせた結果、JCSS の利用拡大が進んだ好例であると

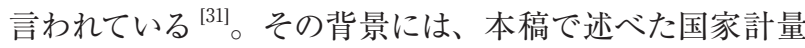
標準の設定、仲介標準器の技術開発、不確かさの評価、 品質システムの整備、国際比較の実施、トレーサビリティ 体系の構築、校正に関する技術文書の作成といった、多く の要素技術が必要であった。1990 年代末から始まった長 期間の取り組みであったが、現段階において、日本国内に は $1550{ }^{\circ} \mathrm{C}$ ま゙の温度計測の信頼性を担保する強固なシス テムが作られた。今後も筆者らは、6.3 節に述べた高度化 への技術開発を続けるとともに、トレーサビリティ体系をよ り有効に使うための一層の普及活動に取り組みたいと考え ている。

\section{用語説明}

用語 1: 熱電対 : 2 種類の金属素線や合金素線から作られ、素 線の選び方により- $270{ }^{\circ} \mathrm{C}$ 極低温から $2400{ }^{\circ} \mathrm{C}$ の超高 温までを測ることができる実用的に優れた温度計。現 在、日本工業規格 (JIS) では T、J、E、K、N の卑金 属熱電対と S、R、B の貴金属熱電対の 8 種類が規定 されている。

用語 2: 温度定点: 物質の相転移が一定の温度で起き、その再 現性・安定性が良いことを利用して温度計の校正を行う 熱平衡状態。代表的なものとしては、水の三重点 (水 の気相・液相・固相が共存する温度)、銅・銀・亜鉛な どの純金属の凝固点がある。

用語 3: 共晶点：一つの融液から二つ以上の固相が分離して密 に混合した組織となって凝固した合金などの融解、もし くは凝固温度。共晶組成で融解・凝固温度の極小点が 得られる。

用語 4:JCSS : Japan Calibration Service System の略で、正 式名称は「計量法校正事業者登録制度」。1993 年 11 月より計量法に基づく校正事業者認定制度として運営さ れ、2005 年 7 月より校正事業者登録制度となった。国 際標準化機構 (ISO) および国際電気標準会議 (IEC) が定めた校正機関に関する基準 (ISO/IEC 17025 規格) の要求事項に適合しているかどうかを審査し、校正事 業者を登録する制度。登録事業者は、JCSS 標章を付 した校正証明書を発行することができる。

用語 5:1990 年国際温度目盛 (ITS-90)：メートル条約加盟国 間の国際的な取り決めによる熱力学温度を近似する温 度目盛。複数の温度定点の温度值と、その間の補間方 法（補間温度計と補間式）で定義される。国際温度目 盛はおよそ 20 年周期で見直しが行われており、1990 年 にその時点での技術に基づき制定された温度目盛が現 在まで使われている。

\section{参考文献}

[1] JIS C 1602, 熱電対. 財団法人日本規格協会, 東京 (1995).

[2] 沼尻治彦, 小倉秀樹, 井土正也, 新井優: 熱電対校正用銀 点実現装置の不確かさ評価, 産業技術総合研究所計量標 準報告, 4 (1), 741-745 (2002).

[3] 小倉秀樹, 沼尻治彦, 山澤一彰, 丹波純, 井土正也, 新井 優: 熱電対用銅点実現装置の不確かさ評価, 計測自動制御 学会論文集, 39 (11), 1016-1021 (2003).

[4] Y.Yamada, F.Sakuma and A.Ono: Thermocouple observations of melting and freezing plateaus for metal-carbon eutectics between the copper and palladium points, Metrologia 37 (1), 71-73 (2000).

[5] H.Ogura, M.Izuchi and M.Arai: Evaluation of cobaltcarbon and palladium-carbon eutectic point cells for thermocouple calibration, Int. J. Thermophys, 29, 210221 (2008).

[6] H.Ogura, M.Izuchi, J.Tamba and M.Arai: Uncertainty for the realization of the $\mathrm{Co}-\mathrm{C}$ eutectic point for calibration of thermocouples, Proc. ICROS-SICE International Conference 2009, 3297-3302 (2009),

[7] 小倉秀樹: $1000{ }^{\circ} \mathrm{C}$ 以上での熱電対の長期安定性の評価技 術, 産総研 Today, 10 (1), 23 (2010).

[8] 小倉秀樹: 熱電対による温度標準の供給, 産総研 Today, 6 (1), 36-37 (2006)

[9] R.E.Bentley: Theory and practice of thermoelectric thermometry, Handbook of Temperature Measurement Vol.3, Springer (1998).

[10] 小倉秀樹: 熱電効果を用いた温度センサ, 計測と制御, 45 (4), 306-311 (2006).

[11] G.W.Burns, D.C.Ripple and M.Battullo: Platinum versus palladium thermocouples: an emf-temperature reference function for the range $0{ }^{\circ} \mathrm{C}$ to $1500{ }^{\circ} \mathrm{C}$, Metrologia, 35, 761-780 (1998).

[12] H. Ogura, H. Numajiri, K. Yamazawa, J. Tamba, M. Izuchi and M. Arai: Effects of heat treatment on the inhomogeneity of the $\mathrm{Pt} / \mathrm{Pd}$ thermocouple at the $\mathrm{Cu}$ freezing point, temperature, Its Measurement and Control in Science and Industry, 7, 485-489 (2003).

[13] G.W.Burns and D.C.Ripple: Variation in the thermoelectric behavior of palladium following heat treatment, Proc. TEMPMEKO 2001, 1, 61-66 (2001).

[14] 小倉秀樹: $\mathrm{Pt} / \mathrm{Pd}$ 熱電対の定点における信頼性, 計測と制 御, 42 (11), 926-929 (2003).

[15] H.Numajiri, H.Ogura, M.Izuchi and M.Arai: Effect of heat treatment on the inhomogeneity of the Pt/ Pd thermocouples at the silver freezing point, Proc. TEMPMEKO 2004, 1, 477-482 (2004).

[16] H.Ogura, K.Yamazawa, M.Izuchi and M.Arai: Emf changes of $\mathrm{Pt} / \mathrm{Pd}$ thermocouples in the range from $1080{ }^{\circ} \mathrm{C}$ to $1330{ }^{\circ} \mathrm{C}$, Proc. TEMPMEKO 2004, 1, 459464 (2004).

[17] M.Izuchi, H.Ogura, H.Narushima, H.Numajiri and M.Arai: Emf changes of $\mathrm{Pt} / \mathrm{Pd}$ thermocouples in the range $420{ }^{\circ} \mathrm{C}$ to $1080{ }^{\circ} \mathrm{C}$, Proc. TEMPMEKO 2004, 1 , 477-482 (2004)

[18] F.Jahan and M.Ballico: APMP regional comparison of Type R (Pt-Pt13\%Rh) thermocouples from 0 to $1100{ }^{\circ} \mathrm{C}$, Metrologia, 44, Tech. Suppl, 03004 (2007).

[19] R.Morice, F.Edler, J.Pearce, G.Machin, J.Fischer and J.R.Filtz: High-temperature fixed-point facilities for improved thermocouple calibration-euromet project 857, Int. J. Thermophys., 29, 231-240 (2008).

[20] F.Edler, R.Morice, H.Ogura and J.Pearce: Investigation of Co-C cells to improve thermocouple calibration, Metrologia, 47, 90-95 (2010). 
[21] 新井 優: 温度の標準供給, AIST Today, 3 (4), 34 (2003).

[22] 独立行政法人 製品評価技術基盤機構: ホームページ http://www.iajapan.nite.go.jp/jcss/lab/index.html

[23] R熱電対のPd点校正を含む共同実験報告, 日本学術振興 会産業計測第36委員会温度計測分科会 (2005).

[24] M.Izuchi, S.Masuyama, H.Ogura and M.Arai: Inhomogeneity evaluation of Type $\mathrm{R}$ thermocouples at the palladium melting point, Proc. SICE 2005, 1499$1502(2005)$

[25] T.Hamada, J.Ode and S.Miyashita: An uncertainty estimation of Type $\mathrm{R}$ thermocouples exposed at $\mathrm{Pd}$ fixed point, Proc. SICE 2005, 1090-1095 (2005).

[26] 独立行政法人 製品評価技術基盤機構: 文書番号JCT21306 技術的要求事項適用指針(接触式温度計(熱電対)).

[27]独立行政法人 製品評価技術基盤機構: H14 16年度 JCSS校正証明書発行件数の推移 http://www.iajapan.nite.go.jp/jcss/pdf/H14-16.pdf

[28] 独立行政法人 製品評価技術基盤機構：H18２0年度 JCSS校正証明書発行件数の推移 http://www.iajapan.nite.go.jp/jcss/pdf/H18-20.pdf

[29] 産総研プレスリリース: 産総研開発の校正用熱電対が民間 企業により実用化, 2006年3月27日.

http://www.aist.go.jp/aist_j/press_release/pr2006/ pr20060327/pr20060327.html

[30] IEC 62460, Temperature - Electromotive force (EMF) tables for pure-element thermocouple combinations. International Electrotechnical Commission (2008).

[31] 社団法人日本電気計測器工業会: JCSSの知識 - 温度計の 校正を例として一, 日本工業出版株式会社, 東京 (2006).

\section{執筆者略歴}

新井 優 (あらいまさる)

1984 年工業技術院計量研究所入所。2001 年産業技術総合研究所計測標準研究部門温度 湿度科高温標準研究室長に就任。現在、計測 標準研究部門副研究部門長、温度湿度科科長 を兼務。高温用の白金抵抗温度計の研究を行 うとともに、抵抗温度計、熱電対のための計量 標準の開発と国際同等性確認の活動に従事。 国際度量衡委員会の測温諮問委員会への日本

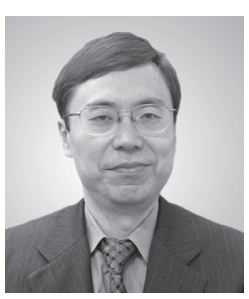
代表。1998 年市村学術賞受賞。日本電気計測器工業会を始め関連 工業会や日本学術振興会などで温度標準と計量トレーサビリティの普 及活動に取り組んでいる。本論文では、温度定点装置の開発と研究 全体の統括を担当した。

\section{小倉 秀樹 (おぐら ひでき)}

2000 年工業技術院計量研究所入所。2001 年産業技術総合研究所計測標準研究部門温度 湿度科高温標準研究室に配属。2007 年から 1 年 4 ケ月間、フランスの国家計量標準機関であ る LNE に客員研究員として滞在し、高温用熱 電対、および熱電対用共晶点の研究を行った。 現在まで、熱電対、及び熱電対用温度定点の 研究開発に従事。日本学術振興会産業計測第

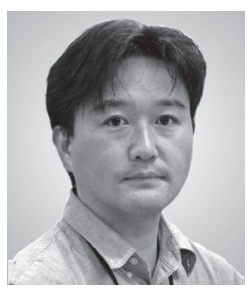
36 委員会温度計測分科会の作業部会にて、現在、副主査として熱 電対校正技術の検討、および信頼性の検証を校正事業者と協力して 行っている。本論文では、熱電対の安定性の研究と共晶点の開発を 担当した。
井土 正也 (いづち まさや)

1980 年工業技術院計量研究所入所。2001 年 産業技術総合研究所計測標準研究部門温度湿 度科高温標準研究室に配属。熱電対の温度標 準の研究開発・校正業務に従事。トレーサビリ テイの信頼性確保のため、技術委員会分科会委 員及び技術アドバイザーとして JCSS の運営・審 查に協力している。本論文では、不確かさ評価 と熱電対校正の品質システムの確立を担当した。

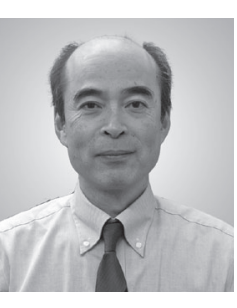

\section{查読者との議論 \\ 議論 1 研究の動機}

コメント・質問 (小野 晃: 産業技術総合研究所)

本論文は、我が国における熱電対のトレーサビリテイ体系を俯瞰的 に設計し、新たな要素技術を開発しつつさまざまな要素技術を統合 し、国際的な動きとも連動させながら社会に受け入れられるトレーサ ビリティ体系を構成していった、優れた第 2 種基礎研究・製品化研 究と思います。身近なところで大量に使われている熱電対だけに、そ れによる温度測定の信頼性が向上することの社会的・産業的な効果 は非常に大きいと思います。

ところで熱電対は高温域では信頼性に問題無きにしもあらずという 指摘が、従来鉄鋼業を中心とした技術者からしばしば出されていま したが、一方では、熱電対は古くから使われている汎用の温度計で あり、先進的な研究を行う余地はもはやないのではないかという見方 もあって、日本では長く研究が下火になっていました。このような状 況の中で著者らが、熱電対に新たな研究要素を見出し、従来よりも 格段に優れた信頼性で熱電対のトレーサビリティ体系を構築したこと を、ある種驚きをもって受け止めています。本研究を開始するに当たっ ての著者らの動機はどのようなものだったのでしょうか。また本研究 の成功の要因は何だったと考えますか。研究の当事者としての経験に 基づいてお聞かせ下さい。

\section{回答 (新井 優、小倉 秀樹、井土 正也)}

熱電対の不均質の問題を正面からとらえることを決意したことが最 大の動機付けであったと思います。本文中で述べましたが、熱電対 は不均質が原因で、温度分布による影響を受けてしまいます。この ため、海外の標準機関においては熱電対の校正に対して、この值は 熱電対が試験された時と同じ状況で使用される場合にのみ適用され る、という限定を付けている場合もあります。しかし、これでは、熱 電対の校正を受けたユーザーは、その值をそのまま利用することが できないことになってしまいます。取り組んですぐに、不均質が、ば らつきではなく、かたよりを生じさせることと、高温にさらされた時間 の経過とともに増大することを、どのように不確かさ評価として扱う かという課題に直面しました。これを私たちは、(1)熱電対の不均質 そのものを小さくする、(2)不均質を適切に評価する、(3)校正を受け るユーザーに事前にユーザーの保有する装置の温度分布のデー夕を 提出してもらい、評価法の妥当性を確認する、という手順で解決を 図りました。

成功した理由は、月並みな言葉ですが、「あきらめず徹底的に追求 したこと」につきるのではないかと思います。不均質の増大を時間的 に追跡することは、根気のいる作業ですが、高精度な校正装置を開 発し、これらの装置を利用して効率的で精密な熱電対の評価方法を 確立できたことが成功の要因の一つであったと思います。今回私たち が行った詳細なレベルまで精密に評価することは、時間と手間がかか るため、なかなか行われていませんでした。効率良く評価ができるよ うになったため、さまざまな条件で実験を行えるようになりました。 これらの結果、従来よりも格段に優れた信頼性で熱電対のトレーサビ リテイ体系を構築できたのだと思います。 


\section{議論2 白金パラジウム熱電対の安定化の要因}

コメント・質問 (濱 純: 産業技術総合研究所評価部)

白金パラジウム熱電対の校正の不確かさの要因とされるドリフトと 不均質を低減させる熱処理条件などを見出し、その不確かさの評価 方法の文書化から、校正方法や品質システムの確立までの一連のプ ロセスは、仲介標準器の開発および企業への高精度の温度計測の還 元のポイントとなる成果です。なお、成果をより明確に理解し、さら に信頼性向上の可能性を推測する意味で、以下の点についてご回答 願います。

白金パラジウム熱電対の場合、ドリフトや不均質の不確かさを抑制 する熱処理条件等のガイドラインは説明されていますが、なぜ安定化 するのかの要因はどのように考えたらよいですか。また、 $\mathrm{R}$ 熱電対で は、同様な熱処理温度ではドリフトや不均質が小さくならないのはな ぜですか。

回答 (新井 優、小倉 秀樹、井土 正也)

図 9 (c) では曝露によってゼーベック係数が増加する傾向のみを 模式的に記載しましたが、白金パラジウム熱電対の場合は、室温か ら $1300{ }^{\circ} \mathrm{C}$ までの温度域では曝露によりゼーベック係数が小さくなる 温度領域と大きくなる温度領域があります。そのため、事前に適切な 温度で十分に長い時間熱処理を行うことにより、素線内部に発生し た電場の熱電対素線に沿った積分値の変化をとても小さくすることが できます。さらに、白金パラジウム熱電対では、曝露によるゼーベッ ク係数の変化は時間の経過とともに飽和する傾向があるので、熱起 電力は最終的に安定化します。一方、 R 熱電対では、 $1000{ }^{\circ} \mathrm{C}$ 付近で 白金ロジウム合金の組成が変化し続けるため、ゼーベック係数は飽 和せずに小さくなり続け、その結果、ドリフト量も飽和せずに起電力 は減少し続けることになります。

\section{議論3 白金パラジウム熱電対の不安定性の微視的原因}

質問 (小野 晃)

白金パラジウム熱電対を特定の温度で最終熱処理することによって ドリフトと不均質を著しく低減できるということは、本研究の重要な 発見と思います。ドリフトと不均質の原因はパラジウム素線の方にあ るとしていますが、パラジウム素線は純金属であり、高温への曝露に よって組成の変化はないように思います。そうするとドリフトと不均質 の低滅の原因は、パラジウム素線の微視的な構造変化が抑制された のかと想像しますが、著者らの見解はいかがでしょうか。またパラジ ウム素線で起こる微視的変化は、材料学や物性論の視点から現在ど の程度まで説明できていますか。

熱電対のドリフトと不均質を低減させるためには、熱処理条件を工 夫すること以外に、原理的に異なる別の方法はないでしょうか。

回答 (新井 優、小倉 秀樹、井土 正也)

パラジウム素線の微視的な構造変化が関係していることは間違い ないと思います。現在、白金パラジウム熱電対のドリフトと不均質の 原因は研究者から幾つか報告されており、大きく分けるとパラジウム 素線に含まれる不純物の酸化、パラジウム素線中の結晶粒の成長、 が考えられています。

パラジウム線中の不純物が原因であるとすれば、パラジウムに含ま れる不純物が酸化して導体から絶縁体になり、その結果、熱起電力 が変化すると考えられます。そのため、今後、更に精製技術が発達し、 高純度のパラジウム線を作製する、もしくは不均質を成長させる不純 物を除去することができれば、不均質の生成を抑制できる可能性が あります。一方、もしパラジウム線中の結晶粒の成長が原因であると すれば、事前の熱処理で結晶を十分に成長させておく方法や、結晶 成長を抑制するために起電力が大きく変化しない程度の添加物を加 えるという方法が考えられます。

以上のように、白金パラジウム熱電対のドリフトと不均質の原因は、 完全にはまだ解明されていないのが現状であり、さらに熱電対校正
の不確かさを小さくするための今後の研究課題であると言えます。

\section{議論4 日本の産業界の貢献と水準}

コメント・質問 (小野 晃)

今回我が国の産業界の技術状況をよく考虑して熱電対のトレーサビ リテイ体系を構築しましたが、諸外国の熱電対のトレーサビリテイ体 系と比べて特徴があるように思います。我が国では民間校正事業者 の多くが、産総研の国家計量標準ほど高度ではないにしても、高温 の定点実現装置を保有し、それぞれ校正事業に活用してきたという 経験があるように思います。民間事業者のこの経験を著者らはうまく 活用して、我が国に世界トップレベルの信頼性のトレーサビリティ体 系を構築できたのではないかと考えるのですが、いかがでしょうか。 著者らが論文の中で繰り返し、「現在までに民間企業が培ってきた技 術」を強調されているのはこのあたりのことでしょうか。

国際比較によって産総研の技術レベルが世界的に高いことが示さ れましたが、もし民間校正事業者同士で国際比較があったならば、 我が国の民間事業者の技術レベルは非常に高いはずと想像します が、いかがでしょうか。

このような技術の信頼性の高さをもっと国際的にアピールしていけ ると良いと思います。

回答 (新井 優、小倉 秀樹、井土 正也)

我が国では、早い時期から温度定点実現装置を保有して、温度計 測の信頼性を高める努力がなされてきました。また、本論文でも述べ た、最新の研究であるコバルトー炭素共晶点を用いた熱電対校正用 装置についても、国内の事業者は産総研との共同研究で既に製品開 発しており、いくつかの校正事業者が、この装置の導入を進めていま す。このように我が国の校正事業者の技術レベルは、極めて高いも のです。もし、校正事業者同士で、校正技術の国際比較が行われれ ば、その信頼性の高さが明らかに示されると思います。さらに、日本 学術振興会産業計測第 36 委員会温度計測分科会の作業部会では、 産総研を含め国内の産業界の熱電対校正事業者が参加して、熱電対 校正技術の共同研究を行っており、これらの研究結果を国際学会な どで積極的に報告していきたいと考えています。

\section{議論5 1550 ㄷ上での熱電対の信頼性}

\section{質問 (小野 晃)}

本研究では $1550{ }^{\circ} \mathrm{C}$ ま゙の範囲で温度のトレーサビリティ体系を構 築しました。一方 $1550{ }^{\circ} \mathrm{C}$ 以上でも熱電対は重要な温度計として使わ れていますが、現状で熱電対の信頼性はどの程度と考えますか。今 後 $1550{ }^{\circ} \mathrm{C}$ 以上の温度範囲で熱電対のトレーサビリティを構築してい くとすれば、どのようなアプローチで研究を進めていくべきと考えま すか。

回答 (新井 優、小倉 秀樹、井土 正也)

熱電対は $1550{ }^{\circ} \mathrm{C}$ 以上の高温でも重要な温度計です。産業界では、 タングステンーレニウム熱電対が $2000{ }^{\circ} \mathrm{C}$ 超える温度まで使用され ています。しかし、タングステンーレニウム熱電対は実際のところ、 信頼性は良く分かっていないのが現状です。例えば、100 時間程度 の使用時間とした場合、おそらく $1700{ }^{\circ} \mathrm{C}$ 付近では $5{ }^{\circ} \mathrm{C}$ 程度、更に 温度が高くなればそれ以上の熱起電力ドリフトがあると思われます。

この温度域では、安定で均一な温度場を作り出すことからして難 しいのですが、加えて、物質の反応性も増すため、絶縁管や保護管 が熱電対素線に与える影響を調べることも必要です。熱電対の安定 性評価に必要なこれらの要素を解決して研究開発を進めていくこと が、信頼性の高い熱電対トレーサビリティを構築するうえで重要にな ると思います。最新の研究成果である、金属一炭素共晶点の高い再 現性を積極的に利用するなどして、研究を進めていきたいと考えてい ます。 